\title{
16. PETROLOGY AND GEOCHEMISTRY OF SILICIFIED UPPER MIOCENE CHALK, COSTA RICA RIFT, DEEP SEA DRILLING PROJECT LEG 691
}

\author{
James R. Hein, U.S. Geological Survey, 345 Middlefield Road, Menlo Park, California \\ Constance Sancetta, Lamont-Doherty Geological Observatory, Palisades, New York \\ and \\ Lisa A. Morgenson, U.S. Geological Survey, 345 Middlefield Road, Menlo Park, California
}

\begin{abstract}
Chert, porcellanite, and other silicified rocks formed in response to high heat flow in the lower 50 meters of 275 meters of sediments at Deep Sea Drilling Project Site 504, Costa Rica Rift. Chert and porcellanite partly or completely replaced upper Miocene chalk and limestone. Silicified rock occurs as nodules, laminae, stringers, and casts of burrows, and consists of quartz and opal-CT in varying amounts, associated with secondary calcite. The secondary silica was derived from dissolution of opal-A (biogenic silica), mostly diatom frustules and radiolarian tests.

Temperature data obtained at the site indicate that transformation of opal-A to opal-CT began at about $50^{\circ} \mathrm{C}$, and transformation from opal-CT to quartz at about $55^{\circ} \mathrm{C}$. Quartz is most abundant close to basement basalts. These silica transformations occurred over the past $1 \mathrm{~m} . \mathrm{y}$., and took place so rapidly that there was incomplete ordering of opal-CT before transformation to quartz; opal-CT formed initially with an uncommonly wide $d$ spacing. Quartz shows poor crystallinity.

Chemical data show that the extensively silicified rocks consist of over $96 \% \mathrm{SiO}_{2}$; in these rocks, minor and trace elements decreased greatly, except for boron, which increased. Low $\mathrm{Al}_{2} \mathrm{O}_{3}$ and $\mathrm{TiO}_{2}$ contents in all studied rocks preclude the presence of significant volcanic or terrigenous detritus. Mn content increases with depth, perhaps reflecting contributions from basalts or hydrothermal solutions. Comparisons with cherts from oceanic plateaus in the central Pacific point to a more purely biogenic host sediment for the Costa Rica Rift cherts, more rapid precipitation of quartz, and formation nearer a spreading center. Despite being closer to continental sources of ash and terrigenous detritus, Costa Rica Rift cherts have lower $\mathrm{Al}_{2} \mathrm{O}_{3}, \mathrm{Fe}_{2} \mathrm{O}_{3}$, and Mn concentrations.
\end{abstract}

\section{INTRODUCTION}

Chert and other siliceous sediment recovered by the Deep Sea Drilling Project have received considerable attention. Many reports focus on details of petrography and mineralogy based on thin sections, SEM, and Xray-diffraction studies. For the Pacific region, detailed studies were published for DSDP Legs 7 (Heath and Moberly, 1971), 16 (Heath, 1973), 17 (Lancelot, 1973), 19 (Hein et al., 1978), 31 (Garrison et al., 1975), 32 (Keene, 1975, 1976), 56 (Pisciotto, 1980), 57 (Iijima et al., 1980), and 62 (Hein et al., 1981; Hein and Yeh, 1981). A compilation of Pacific DSDP data through Leg 32 is provided by Keene (1976), and one for Atlantic data through Leg 50 by Riech and von Rad (1979).

Chert and porcellanite occur as nodules, beds, stringers, and casts of burrows in carbonate sediment drilled during Leg 69. In this report, most aspects of petrology and mineralogy will be discussed only briefly, because many of the petrographic characteristics of Leg 69 cherts are the same as those described in earlier studies. We will present special aspects of the mineralogy, such as quartz crystallinity, opal-CT $d$ spacings, and opal-CT crystallite sizes. Data on the chemical composition of chert, notably lacking in previous studies, will also be discussed. The oxygen-isotope compositions of the chert and porcellanite are presented by Hein and Yeh (this volume).

\footnotetext{
${ }^{1}$ Cann, J. R., Langseth, M. G., Honnorez, J., Von Herzen, R. P., White, S. M., et al., Init. Repts. DSDP, 69: Washington (U.S. Govt. Printing Office).
}

Scientists who studied DSDP Site 504, Leg 69, provided a unique set of measurements that contributed significantly to understanding the process of silicification. These measurements included heat flow, down-hole temperatures, thermal conductivities, pore-water chemi$\mathrm{cal}$ and oxygen-isotope compositions, and the chert and chalk chemical and oxygen-isotope compositions reported here. Site 504 is unique among DSDP sites where silicification has been studied in that the heat flow is very high; consequently, silicification has occurred both rapidly and in young sediments.

\section{GEOLOGIC SETTING}

During Leg 69, chert and porcellanite were recovered only at Site 504, where four holes, including two reentry holes, were drilled on the southern flank of the Costa Rica Rift (Fig. 1) in 3458 to 3460 meters of water. The age of the oceanic crust at Site 504 is about 6.2 m.y., and heat flow is high, about $200 \mathrm{~mW} / \mathrm{m}^{2}$. The sedimentary section is 264 to 274.5 meters thick, consisting mostly of siliceous calcareous ooze and chalk, with varying amounts of admixed volcanic ash, terrigenous debris, and pyrite (Fig. 2). Siliceous microfossils, primarily diatoms and radiolarians, constitute an average of 30 to $40 \%$ of the sediment above the chalk (143.5 m sub-bottom), and about $20 \%$ within the chalk section from 143.5 to 227.2 meters.

In addition, upper Miocene siliceous limestone, chalk, chert, and porcellanite occur from 227.2 meters subbottom depth to basaltic basement. Overall, chert and 


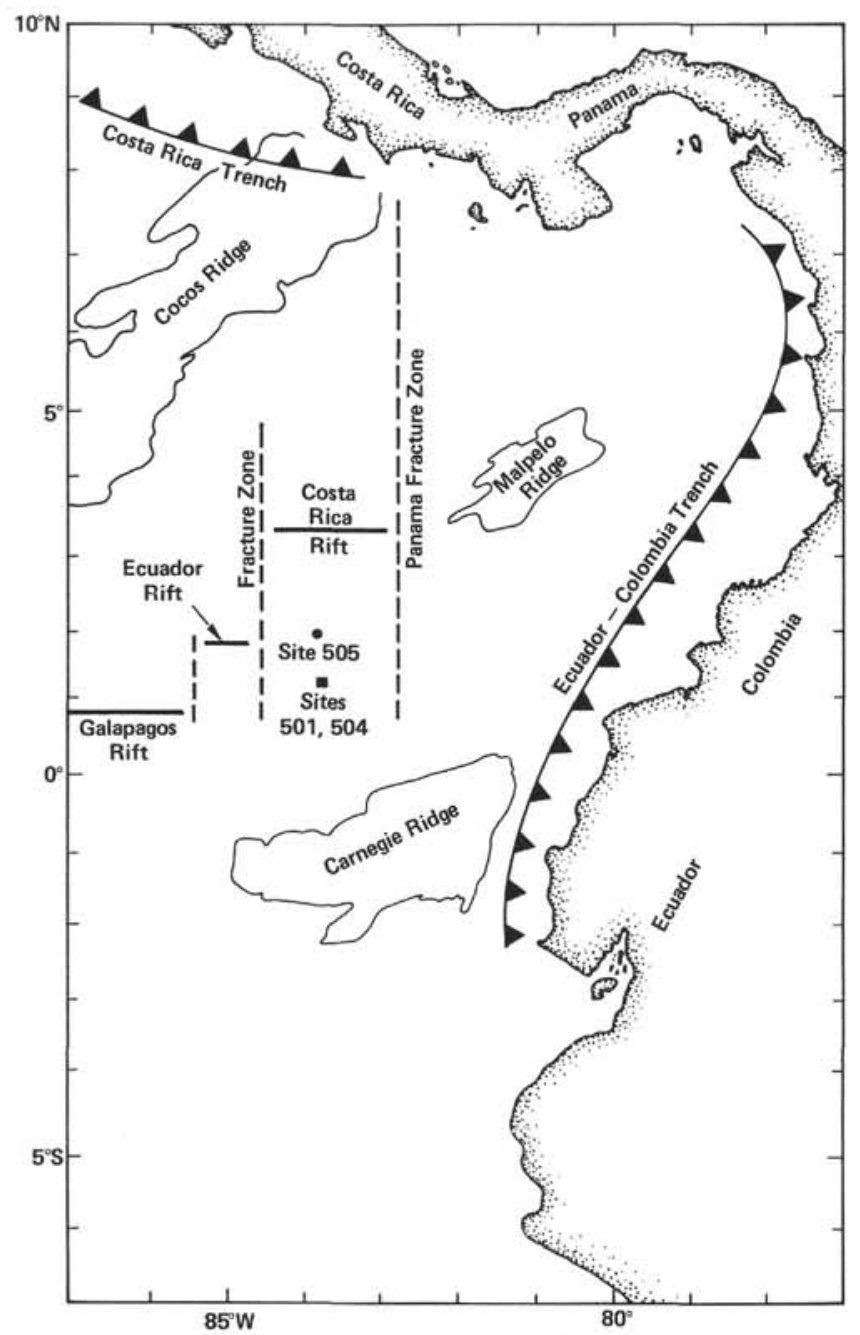

Figure 1. Location of DSDP Leg 69 Sites 504 and 505 and Leg 68 Site 501 ( $200 \mathrm{~m}$ from Site 504). Silicified rocks were cored only from Site 504 during Leg 69; similar silicified rocks at Site 501 have not been studied in detail.

porcellanite make up less than $2 \%$ of the sedimentary section, and probably less than $15 \%$ of the lowermost 40 meters of section; the percentages are difficult to determine because chert beds commonly are fragmented by drilling and mixed with the surrounding chalk.

It is worth noting that the sedimentary section at Site 505 , about $80 \mathrm{~km}$ away, is similar in composition and thickness $(232 \mathrm{~m})$, but shows no diagenetic effects. Surface heat flow at Site 505 is only about $45 \mathrm{~mW} / \mathrm{m}^{2}$ (Langseth et al., this volume). We believe that the greatly increased heat flow at Site 504 is the primary cause of diagenesis.

\section{TERMINOLOGY}

In this paper "chert" is used as a textural term to define a silica-rich, hard, dense, and vitreous sedimentary rock. Porcellanite is a less dense and hard, more porous, siliceous sedimentary rock, commonly with impurities such as clay and carbonate minerals; it has the appearance of unglazed porcelain. We use the terminology of Jones and Segnit (1971) for silica minerals: Opal-

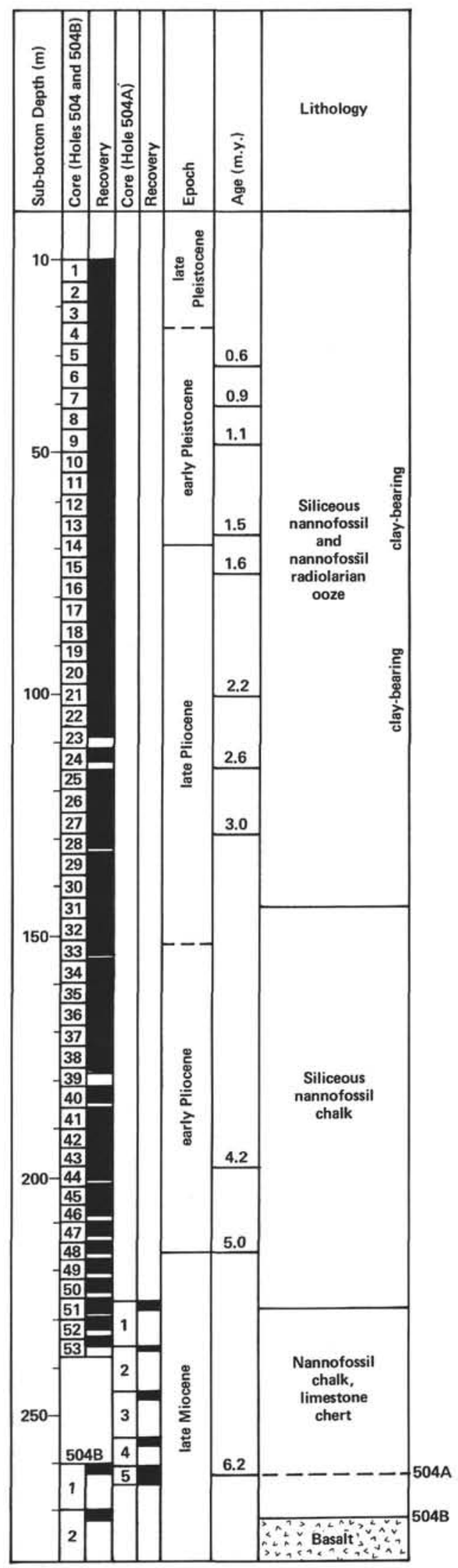

Figure 2. General lithologies, ages, and stratigraphic locations of siliceous rocks of DSDP Leg 69. See Table 1 for a description of each studied rock. 
A is hydrated silica amorphous to X-rays and is the main constituent of biogenic silica, such as radiolarian tests, diatom frustules, silicoflagellates, and sponge spicules; Opal-CT is considered by many investigators to be interlayered $\alpha$-cristobalite and $\alpha$-tridymite (Flörke, 1955), although Oehler (1973), Wilson et al. (1974), and Moore and Gieskes (1980) suggested that opal-CT may be solely tridymite. In general, biogenic opal-A transforms into opal-CT, which in turn transforms into quartz during diagenesis (Murata and Larson, 1975; Hein et al., 1978; Kastner et al., 1977). Typically, but not invariably, the mineralogical transformations are accompanied by textural transformations (siliceous ooze $\rightarrow$ porcellanite $\rightarrow$ chert; Ernst and Calvert, 1969). In the deep sea and in orogenic belts, silica in most cherts is in the form of quartz and chalcedony, whereas silica in most porcellanites occurs as opal-CT. These silica phases can be assumed for the samples studied here unless the terms chert and porcellanite are modified by a mineral name, for example opal-CT chert or quartz porcellanite. Many cherts at Site 504 are opal-CT cherts or mixtures of opalCT and quartz.

\section{METHODS}

Twenty-one chert, porcellanite, and siliceous-chalk samples were analyzed petrographically, as well as by scanning electron microscopy (SEM), energy-dispersive analysis by X-rays (EDAX), X-ray diffraction (XRD), X-ray spectroscopy (XRF), and quantitative emission spectroscopy (ES).

A Cambridge 180 stereoscan SEM-EDAX system was used with gold-palladium-coated samples. HF-etched and untreated fracture surfaces for each sample were compared. Commonly, etched surfaces showed clearer textural and mineralogical relations than did untreated surfaces. The EDAX system was used to delineate the distributions of silica ( $\mathrm{Si}$ ) and calcite (Ca) phases; these minerals are commonly intimately intermixed within the silicified rocks. EDAX also allowed identification of accessory minerals by displaying spectra of the relative abundance of elements that constitute the minerals. Bulk-rock and mineral separates were analyzed by XRD, using a Norelco diffractometer equipped with a curved-crystal carbon monochrometer and theta-compensating slit. Techniques for XRD of silica phases are described in detail by Hein et al. (1978). Opal-CT $d$ spacings were determined after the technique of Murata and Larson (1975), as described by Hein et al. (1978). Quartz crystallinity measurements were made according to the procedure of Murata and Norman (1976). Opal-CT crystallite sizes were measured perpendicular to the $d(101)$ face, using the Scherrer equation (Klug and Alexander, 1954). Quartz/opal-CT ratios were calculated by comparing the combined $4.10 \AA$ cristobalite and $4.24 \AA$ tridymite peak heights to the $3.34 \AA$ quartz peak height. Because of overlap of the $4.246 \AA$ quartz and $4.25 \AA$ tridymite $d$ spacings, $14 \%$ of the quartz $3.34 \AA$ peak height was subtracted from the tridymite peak height. The $86 / 14$ ratio for the primary and secondary quartz peaks was determined from pure quartz cherts from Leg 69. Quartz and opal-CT do not have a 1:1 correlation coefficient; the quartz/opal-CT correlation coefficient depends on the crystallinity of each mineral, and probably falls between 1:6 and 1:9 (Cook et al., 1975; Pisciotto, 1978). The values of relative quartz and opal-CT listed in Table 1 are based on a correlation coefficient of $1: 8$, and thus may be somewhat more or less than the true relative amounts.

Percentages of major oxides plus Mn were determined by X-ray spectroscopy, and minor elements were determined by the U.S. Geological Survey's direct reader quantitative emission spectroscopy technique. Total volatiles were measured in terms of loss on fusion at $1050^{\circ} \mathrm{C}$.

\section{RESULTS}

\section{Stratigraphy and Lithology}

At Site 504, chert occurs as nodules, laminae, stringers, and casts of burrows in calcareous ooze, chalk, and limestone host rock (Fig. 3; Plate 1). All chert occurs in upper Miocene deposits. Stratigraphically the highest cherts are in Cores 50 and 51, Hole 504, at a sub-bottom depth of about 225 meters, where chert occurs as small dispersed chips; the original form of the chert is not known. Cores 53 in Hole 504, 1 through 5 in Hole 504A, and 1 and 2 in Hole 504B also contain chert and porcellanite.

The most common siliceous rock type encountered is partly silicified chalk, which is chalk containing minor to moderate amounts (trace to about $50 \%$ ) of secondary silica cement, mostly opal-CT (Table 1; Plate 3). Next in abundance is calcareous porcellanite, which is simply a more completely silicified chalk and contains moderate to abundant (roughly 50-90\%) secondary silica (Plate 4). Hard, dense, vitreous chert, common to many DSDP cores, is rare in this section; well-developed microcrystalline quartz chert is found mainly as casts of burrows (Plates 1, 5). Chert nodules and laminae with porcellanite rims are present but rare in Leg 69 samples, in contrast to samples from other DSDP legs (Hein et al., 1981; Keene, 1976).

Siliceous rocks range widely in color from white to black. The most common lithologies include light-gray silicified chalk, gray and gray-brown porcellanite, and green-brown to brown chert (Table 1). In general, color darkens with increasing diagenetic grade. Pure chertporcellanite layers and nodules are most commonly less than $2 \mathrm{~cm}$ thick, but incompletely silicified limestone and chalk sections to $15 \mathrm{~cm}$ in thickness occur. Some beds grade from chalk through partly silicified chalk to chert, whereas others have a sharp contact between chert and chalk (Plates 3, Fig. 4; 4, Fig. 3). Most porcellanite and chert contain residual and secondary calcite except in the deepest part of the section, where several microcrystalline quartz cherts are free of calcite (Plate 5, Figs. 3, 4).

In hand sample, chert is vitreous to waxy and grades to porcellanite in less silicified deposits. Siliceous chalk grades imperceptibly to porcellanite, commonly with only a slight change in color; however, hardness and degree of lithification or cementation increase from chalk to porcellanite.

About $88 \%$ of the chert and porcellanite contains obvious burrow structures that were preserved during silicification (Plates 1; 8, Figs. 1, 2). Burrow morphologies are characteristic of Chondrites, Cylindrichnus, Planolites, and Zoophycos (Ekdale, 1977, 1978; Nilsen, 1976). About $24 \%$ of the siliceous rocks are laminated; burrows either occur within single laminae, or transgress from one lamina into an adjacent one (Plate 1, Figs. 1, 3 ). About $70 \%$ of the siliceous rocks are streaked as the result of horizontal burrowing, preferential silicification, or concentrations of hematite, pyrite, and organic matter (Plates 5, Fig. 2; 10, Fig. 6). Twelve percent of the siliceous rocks are massive and without structures.

\section{X-Ray Mineralogy}

Chalk is made up of calcite, with minor amounts of detrital quartz, feldspar, and authigenic pyrite in some deposits (Plate 2). Opal-A, which constitutes 10 to $35 \%$ of the chalks above 230 meters, was recognized on smear 


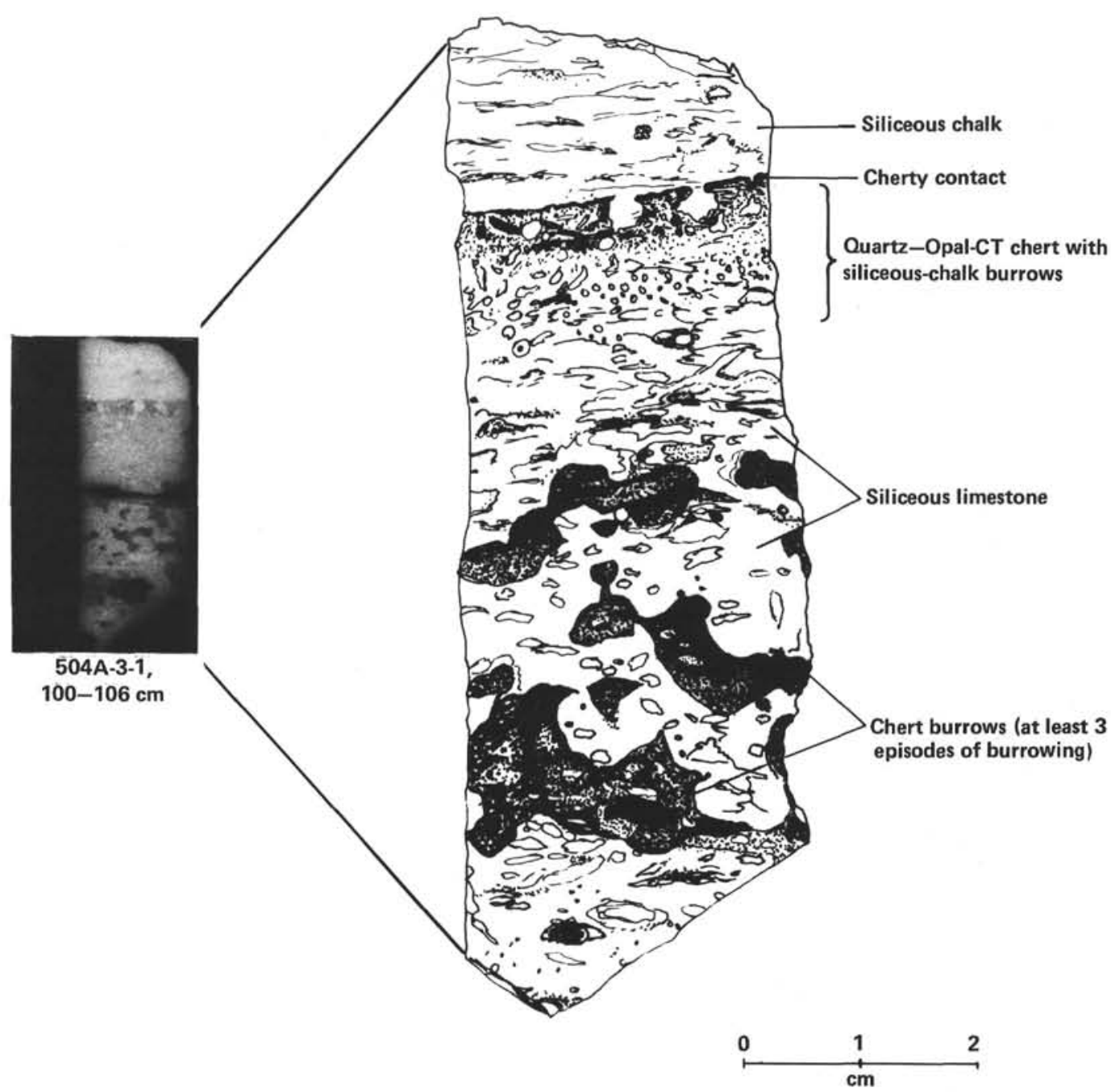

Figure 3. 504A-3-1, 100-106 cm: chalk and highly burrowed porcellanite and chert. The degree of silicification increases with darker shades of gray. The most silicified areas are the large quartz-(chert-) filled burrows and the highly burrowed layer just below the chalk. Drawing by Mary Ann Allan.

slides because it is amorphous to X-rays. Opal-A is indicated by a small increase in X-ray background scatter. These opal-A-bearing calcareous rocks are called siliceous chalk. In contrast, partly silicified chalk, though predominantly calcite, contains minor to moderate amounts of secondary silica in the form of opal-CT and quartz (Plate 3). A strongly silicified chalk, texturally and mineralogically a porcellanite, consists primarily of opal-CT and quartz in varying proportions, with minor to moderate amounts of calcite (Plate 4). The lithologic transformation from siliceous chalk to chert (completely silicified chalk) is accompanied by the mineralogical change of calcite + opal-A $\rightarrow$ opal-CT (by replacement and solution-precipitation) $\rightarrow$ quartz (by solution-precipitation). Many siliceous rocks also contain minor amounts of apatite, pyrite, hematite, and, rarely, detrital quartz and feldspar.

In the few studies of marine chert that considered quartz crystallinity, no systematic changes with age or sub-bottom depth were found (Hathaway, 1972; Murata and Norman, 1976; Riech and von Rad, 1979). Crystallinity does, however, seem to reflect the degree of metamorphism or tectonism to which a chert has been subjected (Murata and Norman, 1976). On Murata and Norman's scale of 10, most Leg 69 cherts (including all samples with secondary quartz) fall below 1 (Table 1), indicating the poor crystallinity (equivalent to very small grain size) typical of diagenetic quartz. The seven samples with quartz crystallinities greater than 1 are from rocks that are texturally cherts. Variations in quartz crystallinity are not clearly related to depth in Leg 69 siliceous rocks. Hein et al. (1981) noted a poorly defined trend in Leg 62 rocks indicating that older cherts are more likely to have better crystallinity than younger ones. No trend was noted for crystallinity versus subbottom position of cherts, which, in conjunction with the Leg 69 results, suggests that time plays a greater role than does depth of burial in the maturation of quartz. 
As all Leg 69 cherts are essentially late Miocene in age, a systematic change in quartz crystallinity perhaps should not be expected.

Opal-CT $d$ spacings range from $4.084 \AA$ to $4.131 \AA$, the latter spacing being one of the largest reported for siliceous rocks. The average $d$ spacing for Site 504 rocks is $4.107 \AA$ (standard deviation 0.012). The range of $d$ spacings of opal-CT in cherts and porcellanites determined in other studies is $4.040 \AA$ to $4.120 \AA$ (Murata and Nakata, 1974; Hein et al., 1978), but in the Miocene Monterey Formation and DSDP Leg 62 cherts, opal-CT reaches a minimum $d$ spacing of about $4.07 \AA$ before converting to quartz (Pisciotto, 1978; Hein et al., 1981); for porcellanite, however, conversion to quartz should occur between $4.04 \AA$ and $4.07 \AA$. Because no values less than $4.084 \AA$ exist and because abundant opal-CT-quartz siliceous rocks occur in Leg 69 deposits, opal-CT in Leg 69 rocks probably reached a minimum $d$ spacing of $4.084 \AA$ prior to conversion to quartz, the largest welldefined minimum $d$ spacing thus far reported for siliceous rocks. Thus, Leg 69 siliceous rocks have both the largest minimum and largest maximum opal-CT $d$ spacings known.

Opal-CT $d$ spacings generally decrease with increasing depth and temperature and with time in siliceous sections on land and below the sea bed along continental margins (Murata and Nakata, 1974; Mitsui, 1975; Hein et al., 1978). Similar relationships between crystal structures and depth have not been noted in abyssal oceanicbasin deposits, except in North Pacific Leg 62 deposits, where a poorly defined trend of smaller $d$ spacings occurs with increasing depth (Hein et al., 1981). The silicified chalks from Holes 504 and 504A combined appear to have a trend toward smaller opal-CT $d$ spacings with increasing depth (Fig. 4), though data from the other lithologies are equivocal.

Opal-CT crystallite sizes range from $65 \AA$ to $96 \AA$, averaging $82 \AA$ (standard deviation $7 \AA$ ), essentially the same range as that measured for Leg 62 cherts. No trend in crystallite size with increasing depth is found in the Leg 69 section (Fig. 4).

Quartz/opal-CT ratios, quartz crystallinities, opalCT $d$ spacings, and opal-CT crystallite sizes were measured on a fine scale through a single bed in order to determine whether there are progressive changes from the edges to the center of the bed (Table 2). For the selected samples only opal-CT $d$ spacings show a progressive change from the rims inward. Toward the base of the bed, silicification is most advanced, and the greatest amount of secondary quartz occurs. Quartz/opalCT ratios show that the bed contains significantly more quartz than do the rims. The opal-CT $d$ spacings are perhaps surprising, because $d$ spacings increase (crystals become less ordered) toward the area of more advanced silicification. Opal-CT $d$ spacing should shorten before the mineral converts to quartz. These data can be interpreted in several ways. Either early-formed opal-CT in the most silicified part of the bed may have been converted to quartz, the opal-CT being a second, relatively newly formed mineral, or, alternatively, the $4.103 \AA$
opal-CT may be minor "residual" opal-CT that did not order and thus was not converted to quartz. Additional possibilities exist, and conclusions that could be generally applicable cannot be drawn with certainty from this analysis of one bed.

\section{Thin-Section and SEM Petrography}

Leg 69 porcellanites and cherts are cemented and replaced chalks that are petrographically similar to those associated with calcareous rocks described for other DSDP Pacific sites (Heath and Moberly, 1971; Lancelot, 1973; Keene, 1975; Hein et al., 1981). In general, Leg 69 siliceous rocks contain more calcite and are diagenetically less mature than other silicified chalks. Less advanced diagenesis probably results both from the youth of the deposits (about 5 m.y., versus 30 to 40 m.y. for the youngest cherts recovered at other sites), and from rapid and consequently incomplete silicification driven by the very high heat flow at Site 504. Rapid silicification resulted in petrographic textures characterized by much carbonate debris floating or included in the porcellanite and chert, and by ghosts of carbonate masses replaced by opal-CT enclosed in microcrystalline quartz. In many thin-sections, silica polymorphs were frozen at the "moment" of transformation; that is, mineralogically the rock is quartz, but optically the rock appears to consist of opal-CT with very low to no birefringence (Plates 1, Fig. 3; 8, Figs. 1, 2). Diagenesis thus appears to be mostly in incipient stages.

The host siliceous chalk consists mainly of coccoliths and anhedral calcite grains that include both cement and disaggregated plates of coccoliths (Plates 2, Figs. 5, 6; 3, Figs. 1, 2, 4). Small amounts of iron commonly substitute for calcium in calcite cement and in calcite overgrowths on coccoliths. The presence of iron in siliceous chalks was determined by EDAX.

Diatoms, foraminifers, and discoasters are present in all studied chalks, and are common in some (Plates 2, Figs. 1-4; 6, Fig. 5). Although diatoms and radiolarians have been virtually eliminated by wholesale dissolution below 234 meters, where silicification is most profound, traces of these siliceous organisms are found in the chalk down to basement (Plate 2, Fig. 4). Sample 504A-5-1, $70-72 \mathrm{~cm}(262 \mathrm{~m})$ is especially rich in diatoms. These diatoms apparently were protected from dissolution by coatings of iron oxide on frustules (Plate 2, Fig. 4). Discoasters are also abundant in this sample (Plate 2, Fig. 2). Diatoms in chalk above Core $53(237 \mathrm{~m})$ show mild etching, if any. Diatoms are commonly highly fragmented, yet coexist with fragile coccospheres (Plate 2, Figs. 1-5). Trace amounts of detrital clay minerals, quartz, feldspar, volcanic glass, and authigenic pyrite also occur in chalk.

Immediately above the chert-limestone unit is a short interval at both Sites 501 and 504 with abundant diatoms $(226-237 \mathrm{~m})$. These diatoms are extremely well preserved and are dominated by needle-like species which give an open, porous texture to the sediment (Plate 11, Figs. 1-3). Within this same interval, in 504-52,CC (231 $\mathrm{m})$, is a layer of large, euhedral pyrite crystals (Plate 12, 


\section{J. R. HEIN, C. SANCETTA, L. A. MORGENSON}

Table 1. Characteristics of DSDP Leg 69 late Miocene siliceous rocks and associated rocks.

\begin{tabular}{|c|c|c|c|}
\hline $\begin{array}{l}\text { Sample } \\
\text { (interval in } \mathrm{cm} \text { ) }\end{array}$ & $\begin{array}{l}\text { Sub-bottom } \\
\text { Depth } \\
\text { (m) }\end{array}$ & Lithology & $\begin{array}{l}\text { Thin-Section } \\
\text { Description }\end{array}$ \\
\hline $504-52-1,94-96$ & 230.9 & Siliceous chalk & \\
\hline $504-53-1,10-14$ & 234.1 & $\begin{array}{l}\text { 1. Fe-rich siliceous chalk coating } \\
\text { 2. Greenish-tan calcareous } \\
\text { opal-CT chert }\end{array}$ & \\
\hline $504-53-1,21-23$ & 234.2 & Siliceous chalk & \\
\hline $504 \mathrm{~A}-1, \mathrm{CC} 1$ & 227.0 & $\begin{array}{l}\text { Extensively burrowed greenish-tan } \\
\text { calcareous porcellanite }\end{array}$ & \\
\hline $504 \mathrm{~A}-1, \mathrm{CC}$ II & 227.0 & $\begin{array}{l}\text { 1. Laminated and burrowed, white, } \\
\text { partly silicified chalk; and } \\
\text { 2. Burrowed gray-tan calcareous chert }\end{array}$ & $\begin{array}{l}\text { Chalk with opal-CT burrows containing radiolarians and foraminifers } \\
\text { filled with chalcedony and some opal-CT; many foraminifers in } \\
\text { chalk, filled mostly with calcite and rarely with opal-CT; pyrite- } \\
\text { replaced radiolarians }\end{array}$ \\
\hline $504 \mathrm{~A}-2, \mathrm{CC}$ & 236.0 & $\begin{array}{l}\text { 1. White, partly silicified chalk, in } \\
\text { contact with: } \\
\text { 2. Burrowed and streaked, gray } \\
\text { calcareous porcellanite }\end{array}$ & $\begin{array}{l}\text { Chalk with opal-CT-filled burrows containing radiolarians and } \\
\text { foraminifers filled with chalcedony and some opal-CT; many } \\
\text { foraminifers in chalk, filled mostly with calcite; in gradational con- } \\
\text { tact with chalk containing diffuse patches of opal-CT and laminae } \\
\text { of pure chalk; pyrite vein }\end{array}$ \\
\hline $504 A-3-1,59-61$ & 246.1 & $\begin{array}{l}\text { 1. White, partly silicified chalk } \\
\text { 2. Greenish-brown, calcareous chert } \\
\text { and porcellanite }\end{array}$ & $\begin{array}{l}\text { Opal-CT-replaced burrows with opal-CT- and chalcedony-filled } \\
\text { radiolarians and foraminifers; chalk with calcite-filled and } \\
\text { recrystallized foraminifers; pyrite, hematite, and quartz stringers; } \\
\text { some phosphatic debris; sharp contacts; preferred orientation of } \\
\text { elongate fossils and quartz stringers; chalk patches in porcellanite }\end{array}$ \\
\hline $504 \mathrm{~A}-3-1,70-73$ & 246.2 & Calcareous mud & \\
\hline $504 \mathrm{~A}-3-1,90-93$ & 246.4 & Partly silicified chalk & \\
\hline $504 \mathrm{~A}-3-1,100-106$ & 246.5 & $\begin{array}{l}\text { (top to bottom) } \\
\text { 1. White, partly silicified chalk, } \\
\text { burrowed into: } \\
\text { 2. Gray-brown calcareous porcellanite } \\
\text { that contains several generations of } \\
\text { burrows; and: } \\
\text { 3. Sparsely burrowed calcareous } \\
\text { porcellanite with several generations } \\
\text { of burrows, including one striking } \\
\text { set of large burrows replaced by: } \\
\text { 4. Gray-brown chert }\end{array}$ & $\begin{array}{l}\text { Chalk layer with pyrite stringer; layer with extensive opal-CT burrows } \\
\text { in chalk containing pyrite- and opal-CT-replaced radiolarians; chalk } \\
\text { layer with isolated opal-CT burrows; calcite- and quartz-filled } \\
\text { foraminifers in chalk and layer of chalk with distinct quartz-and } \\
\text { opal-CT-filled burrows with aggrading neomorphism of quartz; } \\
\text { pyrite and apatite (fish debris) }\end{array}$ \\
\hline $504 \mathrm{~A}-4-1,45-48$ & 255.5 & $\begin{array}{l}\text { Laminated to burrowed, light-gray, } \\
\text { partly silicified chalk }\end{array}$ & \\
\hline $504 \mathrm{~A}-4-1,81-84$ & 255.8 & $\begin{array}{l}\text { 1. Laminated to burrowed, light-gray. } \\
\text { partly silicified chalk, in contact } \\
\text { with: } \\
\text { 2. Burrowed, gray-brown, calcareous } \\
\text { porcellanite }\end{array}$ & $\begin{array}{l}\text { Chalk mixed with opal-CT with opal-CT- and calcite-filled foraminifers } \\
\text { hematite-rich area; pyrite }\end{array}$ \\
\hline $504 \mathrm{~A}-4-1,110-112$ & 256.1 & Dark-grayish-brown chert & $\begin{array}{l}\text { Microgranular quartz with scattered calcite, hematite-rich areas; } \\
\text { radiolarian and foraminifer ghosts; pure-quartz-chert laminae; } \\
\text { apatite; pyrite; chalcedony veins }\end{array}$ \\
\hline $504-5-1,8-12$ & 261.1 & $\begin{array}{l}\text { 1. Burrowed, light-gray, calcareous } \\
\text { porcellanite, and } \\
\text { 2. Partly silicified chalk, containing } \\
\text { extensively burrowed: } \\
\text { 3. Dark-gray-brown, calçareous chert }\end{array}$ & $\begin{array}{l}\text { Chalk incompletely replaced by opal-CT; opal-CT replaces along Fe- or } \\
\text { organic-matter-rich stringers; opal-CT with microquartz stringers } \\
\text { and microquartz-filled radiolarians and foraminifers; phosphatic } \\
\text { debris; pyrite; preferred orientation of elongate foraminifers }\end{array}$ \\
\hline 504A-5-1, 37-39 & 261.4 & $\begin{array}{l}\text { 1. Very dark-brown, burrowed chert, } \\
\text { with: } \\
\text { 2. Light-gray, calcareous porcellanite } \\
\text { rims }\end{array}$ & $\begin{array}{l}\text { Microcrystalline quartz with radiolarian ghosts, foraminifers of coarser } \\
\text { quartz rimmed by a thin, opal-CT band and thin calcareous } \\
\text { porcellanite consisting of mixed opal-CT patches and stringers in } \\
\text { chalk; thin calcite veins in microquartz and porcellanite and quartz } \\
\text { vein in porcellanite }\end{array}$ \\
\hline \multirow[t]{6}{*}{$504 A-5-1,52-54$} & \multirow[t]{6}{*}{261.5} & $\begin{array}{l}\text { (laminae, top to bottom) } \\
\text { 1. Gray, partly silicified chalk }\end{array}$ & 1. Chalk with abundant foraminifers \\
\hline & & 2. Stratabound pyrite in chalk & $\begin{array}{l}\text { 2. Stringers, lenses, masses, and spheres of pyrite in chalk containing } \\
\text { many foraminifers, some partly filled with pyrite }\end{array}$ \\
\hline & & 3. Black, calcareous chert nodule & $\begin{array}{l}\text { 3. Microcrystalline quartz nodule with opal-CT rim; foraminifers } \\
\text { replaced by and filled with chalcedony plus quartz; hematite } \\
\text { stringers; pyrite }\end{array}$ \\
\hline & & $\begin{array}{l}\text { 4. White and gray, partly silicified } \\
\text { chalk }\end{array}$ & $\begin{array}{l}\text { 4. Chalk with minor and small foraminifers and dendritic material of } \\
\text { unknown composition (possibly phosphatic debris); patches; burrow- } \\
\text { ing in lamina \#5 }\end{array}$ \\
\hline & & $\begin{array}{l}\text { 5. Brown, highly burrowed, calcareous } \\
\text { chert }\end{array}$ & $\begin{array}{l}\text { 5. Highly burrowed opal-CT and microquartz with radiolarian and } \\
\text { foraminifer ghosts; patches from both upper and lower laminae, } \\
\text { relict texture of abundant broken skeletal debris; layer undergoing } \\
\text { phase transition from opal-CT to microquartz }\end{array}$ \\
\hline & & $\begin{array}{l}\text { 6. White and gray, partly silicified } \\
\text { chalk }\end{array}$ & 6. Chalk with many foraminifers as in $\# 1$, and dendritic material, as in \\
\hline \multirow[t]{2}{*}{$504 A-5-1,61-64$} & \multirow[t]{2}{*}{261.6} & $\begin{array}{l}\text { 1. Light-gray, partly silicified chalk, } \\
\text { with: }\end{array}$ & \multirow[t]{2}{*}{$\begin{array}{l}\text { 1. Chalk with foraminifer-rich and foraminifer-poor laminae; dendritic } \\
\text { pattern of phosphatic(?) debris; phosphatic grains and pyrite; trace } \\
\text { of detrital quartz, feldspar; volcanic-rock fragments }\end{array}$} \\
\hline & & $\begin{array}{l}\text { 2. Burrows filled by gray-brown, cal- } \\
\text { careous porcellanite and chert }\end{array}$ & \\
\hline $504 A-5-1,70-72$ & 261.7 & $\begin{array}{l}\text { 1. Light-gray, burrowed, partly } \\
\text { silicified chalk, plus: } \\
\text { 2. Gray-brown, extensively burrowed, } \\
\text { calcareous porcellanite and chert }\end{array}$ & $\begin{array}{l}\text { Opal-CT-quartz-filled burrow area, bounded above by chalk with rare } \\
\text { volcanic rock fragments, and below by mixed chalk-opal-CT-quartz } \\
\text { zone with foraminifers and radiolarians filled with quartz }\end{array}$ \\
\hline $504 \mathrm{~A}-5-1,75-78$ & 261.8 & $\begin{array}{l}\text { Extensively burrowed chalk, almost } \\
\text { completely replaced by silica: } \\
\text { 1. Large burrow filled by very dark } \\
\text { brown chert, bounded by: } \\
\text { 2. Gray-brown chert, both set in: } \\
\text { 3. Light-gray, calcareous porcellanite }\end{array}$ & $\begin{array}{l}\text { Microquartz-filled burrows containing coarser quartz-filled microfossils, } \\
\text { stringers of hematite, pyrite; chalk inclusions in burrow replaced by } \\
\text { opal-CT; microquartz burrow rimmed by opal-CT, in places with } \\
\text { quartz stringers; chalk with many calcite- and quartz-filled } \\
\text { microfossils }\end{array}$ \\
\hline 504B-1-1, 63-68 & 261.0 & $\begin{array}{l}\text { 1. Gray-brown, calcareous porcellanite, } \\
\text { with: } \\
\text { 2. Gray to dark-brown, calcareous por- } \\
\text { cellanite and chert-filled burrows }\end{array}$ & \\
\hline 504B-2-1, 85-92 & 270.9 & $\begin{array}{l}\text { 1. White, calcareous mud, above: } \\
\text { 2. Laminated, gray-brown, calcareous } \\
\text { porcellanite }\end{array}$ & \\
\hline
\end{tabular}


Table 1. (Continued).

\begin{tabular}{|c|c|c|c|c|c|c|}
\hline Major & $\begin{array}{l}\text { General X-ray Mineralogy } \\
\text { Moderate }\end{array}$ & Trace & $\begin{array}{c}\text { Quartz } \\
(\text { Opal-CT } \times 8)\end{array}$ & $\begin{array}{c}\text { Quartz } \\
\text { Crystallinity }\end{array}$ & $\begin{array}{l}\text { Opal-CT } \\
d \text { Spacing } \\
(\dot{\AA})\end{array}$ & $\begin{array}{c}\text { Opal-CT } \\
\text { Crystallite } \\
\text { Sizes } \\
(\AA)\end{array}$ \\
\hline $\begin{array}{l}\text { Calcite } \\
\text { 1. Calcite } \\
\text { 2. Calcite, opal-CT }\end{array}$ & Pyrite, marcasite, magnetite & $\begin{array}{l}\text { Quartz } \\
\text { Quartz, opal-CT? } \\
\text { Quartz }\end{array}$ & 0.02 & & 4,131 & 69 \\
\hline $\begin{array}{l}\text { Calcite } \\
\text { Calcite }\end{array}$ & Quartz, opal-CT & & 0.06 & $<1$ & 4.119 & 82 \\
\hline 1. Calcite & Opal-CT & Apatite? & 0.11 & & 4.110 & 87 \\
\hline 2. Calcite & Quartz, opal-CT & & 0 & & 4.116 & 80 \\
\hline 1. Calcite & Opal-CT & & 0.01 & & 4.114 & 86 \\
\hline 2. Calcite, opal-CT & & Quartz & 0.03 & & 4.122 & 84 \\
\hline $\begin{array}{l}\text { 1. Calcite } \\
\text { 2. Quartz }\end{array}$ & Opal-CT, calcite & Opal-CT & $\begin{array}{l}0.05 \\
0.22\end{array}$ & $1.2-1.5$ & $\begin{array}{l}4.101 \\
4.110\end{array}$ & $\begin{array}{l}83 \\
86\end{array}$ \\
\hline $\begin{array}{l}\text { Calcite } \\
\text { Calcite }\end{array}$ & & $\begin{array}{l}\text { Quartz, zeolite? } \\
\text { Opal-CT, quartz }\end{array}$ & 0 & & 4.114 & 74 \\
\hline 1. Calcite & Opal-CT & Quartz & 0.03 & (no peak) & 4.110 & 90 \\
\hline 2. Quartz, calcite, opal-CT & & & 0.30 & (no peak) & 4.114 & 96 \\
\hline $\begin{array}{l}\text { 3. Quartz, calcite } \\
\text { Calcite } \\
\text { Calcite }\end{array}$ & $\begin{array}{l}\text { Opal-CT } \\
\text { Opal-CT, quartz } \\
\text { Opal-CT }\end{array}$ & Quartz & $\begin{array}{l}0.16 \\
0.06 \\
0.04\end{array}$ & $\begin{array}{l}<1 \\
<1 \\
<1\end{array}$ & $\begin{array}{l}4.108 \\
4.116 \\
4.118\end{array}$ & $\begin{array}{l}88 \\
84 \\
79\end{array}$ \\
\hline $\begin{array}{l}\text { 4. Quartz } \\
\text { Calcite }\end{array}$ & Opal-CT & $\begin{array}{l}\text { Calcite? } \\
\text { Opal-CT, zeolite }\end{array}$ & $\begin{array}{l}0.22 \\
0\end{array}$ & $<1$ & $\begin{array}{l}4.101 \\
4.093\end{array}$ & $\begin{array}{l}67 \\
84\end{array}$ \\
\hline 1. Calcite & & Opal-CT, zeolite, quartz & $0.0 \mathrm{I}$ & & 4.101 & 86 \\
\hline 2. Calcite, opal-CT & & Quartz & 0.02 & & 4.118 & 83 \\
\hline Quartz & & Calcite & $100 / 0$ & $<1$ & & \\
\hline 1. Calcite & Opal-CT & Quartz & 0 & & 4.103 & 79 \\
\hline $\begin{array}{l}\text { 3. Quartz } \\
\text { 1. Quartz }\end{array}$ & Opal-CT, calcite & Calcite & $\begin{array}{c}0.14 \\
100 / 0\end{array}$ & $\begin{array}{l}<1 \\
2.1\end{array}$ & 4.112 & 76 \\
\hline 2. Calcite, quartz, opal-CT & & & 0.14 & $<1$ & 4.107 & 89 \\
\hline 1. Calcite & & Opal-CT, phosphate & 0.06 & $<1$ & 4.084 & 75 \\
\hline 3. Quartz & Calcite & Opal-CT & $100 /$ trace & $1.2-1.5$ & & \\
\hline 4. Calcite & & Opal-CT & 0 & & 4.094 & 73 \\
\hline Calcite & & Opal-CT, quartz, phosphate? & 0.03 & & 4.102 & 92 \\
\hline 5. Quartz, calcite & Opal-CT & & 0.49 & $1.1-1.2$ & 4.110 & 80 \\
\hline 6. Calcite & Opal-CT & Quartz & 0.08 & $<1$ & 4.086 & 78 \\
\hline 1. Calcite & Opal-CT & phosphate & 0 & & 4.095 & 81 \\
\hline 2. Quartz & Calcite, opal-CT & & 0.45 & $1.2-1.5$ & 4.099 & 85 \\
\hline 1. Calcite & Opal-CT & Quartz & 0 & & 4.086 & 89 \\
\hline 2. Quartz, calcite, opal-CT & & & 0.10 & $<1$ & 4.094 & 65 \\
\hline 1. Quartz & & & $100 / 0$ & $1.8-2.0$ & & \\
\hline 2. Quartz & Opal-CT & Calcite & 0.19 & $1.2-1.5$ & 4.099 & 85 \\
\hline 3. Calcite, opal-CT & Quartz & & 0.05 & $<1$ & 4.104 & 94 \\
\hline 1. Calcite, opal-CT & & Quartz & 0.01 & & 4.129 & 72 \\
\hline 2. Opal-CT & Calcite, quartz & & 0.042 & $<1$ & 4.127 & 79 \\
\hline 1. Calcite & & Quartz, zeolite?, opal-CT & & & & \\
\hline 2. Calcite & Quartz, opal-CT & & 0.09 & $<1$ & 4.110 & 83 \\
\hline
\end{tabular}



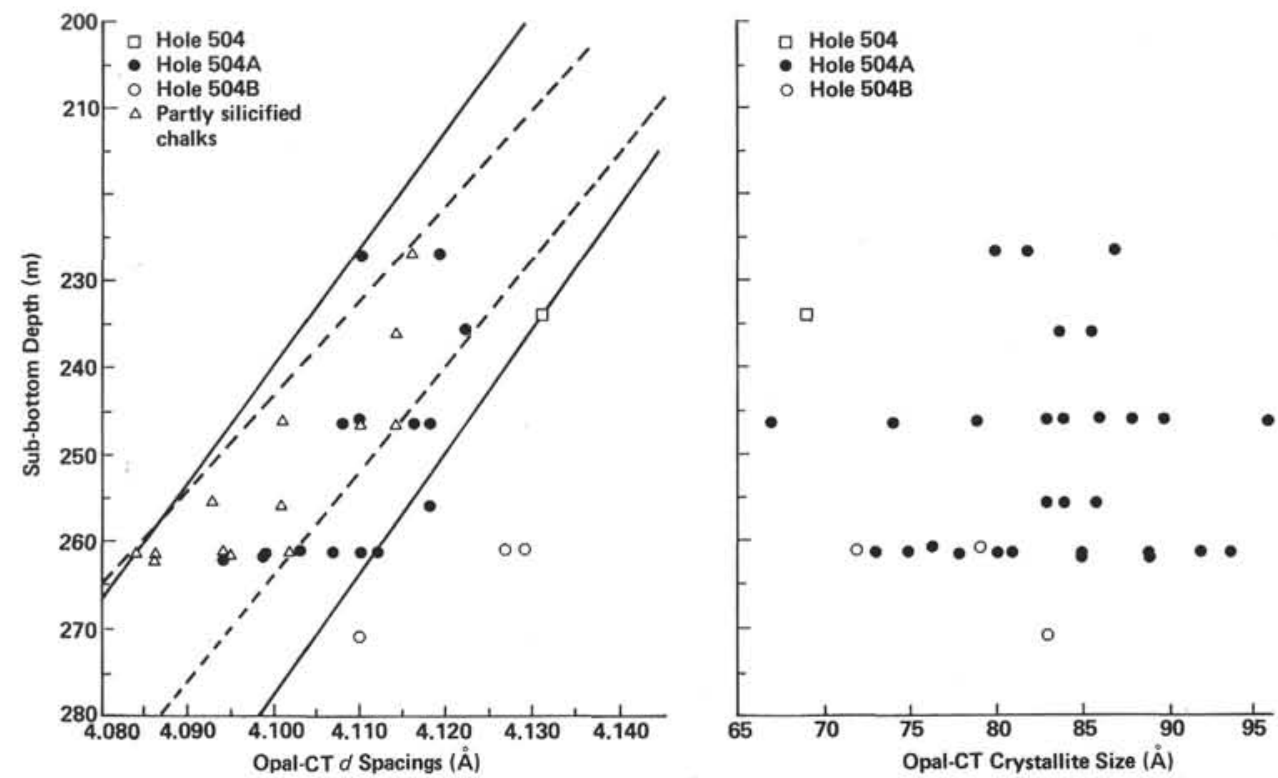

Figure 4. Variations of opal-CT crystallite sizes and $d$ spacings with increasing depth at Site 504 cores. The opal-CT $d$ spacings, exclusive of Hole 504B, show a tendency (albeit poorly defined) to decrease with depth (values enclosed within solid lines). If $d$ spacings from partly silicified chalks are the only ones plotted, then the trend becomes better defined (values denoted by triangles and bounded by dashed lines). Opal-CT crystallite sizes show no trend related to sub-bottom depth.

Table 2. Quartz/(Opal-CT $\times 8)$ ratios, quartz crystallinity, opal-CT $d$ spacings, and opal-CT crystallite sizes across a single calcareous porcellanitechert bed, DSDP Leg 69.

\begin{tabular}{|c|c|c|c|c|c|}
\hline Sample & Description and Approximate Location in Bed & $\begin{array}{c}\text { Quartz } \\
(\text { Opal-CT } \times 8)\end{array}$ & $\begin{array}{c}\text { Quartz } \\
\text { Crystallinity }\end{array}$ & $\begin{array}{c}\text { Opal-CT } \\
d \text { Spacing } \\
(\AA)\end{array}$ & $\begin{array}{c}\text { Opal-CT } \\
\text { Crystallite } \\
\text { Sizes } \\
(\AA ̊)\end{array}$ \\
\hline $504 \mathrm{~A}-5-1,70-72 \mathrm{~cm} \# 1$ & Upper, partly silicified chalk rim & 0.05 & $\ll 1$ & 4.093 & 74 \\
\hline \#2 & Upper, partly silicified chalk rim $\sim 6 \mathrm{~mm}$ wide, below \#1 & 0.04 & $\ll 1$ & 4.097 & 86 \\
\hline \#3 & Calcareous porcellanite $\sim 5 \mathrm{~mm}$ wide, below \#2 & 0.10 & $\ll 1$ & 4.101 & 84 \\
\hline \#4 & Calcareous porcellanite $\sim 3 \mathrm{~mm}$ wide, below \#3 & 0.21 & $<1$ & 4.103 & 94 \\
\hline \#5 & Partly silicified chalk rim $\sim 2 \mathrm{~mm}$ wide, below \#4 & 0 & - & 4.101 & 86 \\
\hline \#6 & Partly silicified chalk rim $\sim 4 \mathrm{~mm}$ wide, below \#5 & 0 & - & 4.090 & 92 \\
\hline
\end{tabular}

Figs. 1, 2). This layer, within the first interval of early silicification, and just above the level of abundant secondary silica, may represent a diagenetic front.

Early silicification is manifested as bladed opal-CT cement if sufficient pore space is available (Plate 3, Fig. 3 ), or as massive opal-CT cement if pore space is inadequate (Plate 3, Figs. 5, 6). The opal-CT in part replaces nannofossils while preserving the fine coccolith structures. Foraminifer chambers are filled with secondary calcite, opal-CT, and/or quartz. All combinations of these three minerals are present as chamber fillings, even within a single thin-section (Plates 4, Figs. 2, 3; 6, Figs. 1-4; 7, Figs. 1-3; 9, Figs. 1-6; 10, Figs. 1, 2). Initial silicification favors large burrows, extensively burrowed laminae, and, rarely, organic-rich laminae (Plates 1; 5, Fig. 2). Chalk in burrows is cemented or replaced by opal-CT. Commonly, irregular or spherical masses of chalk are included in the silicified burrows. Burrows replaced by opal-CT contain radiolarians and foraminifers replaced by quartz and filled with chalcedony, microgranular quartz, and/or opal-CT. In the surrounding chalk, and in included masses of chalk, foraminifer walls are calcite, locally recrystallized, often with secondary calcite filling the chambers. The distinction between foraminifer replacement and chamber filling in opal-CT and in chalk is always sharp. A test that straddles the boundary between an opal-CT-replaced burrow and an included mass of chalk was replaced by quartz in the part that is in the opal-CT, and by recrystallized calcite in the part that is in the chalk; chambers in the opal-CT were filled by chalcedony, whereas those in the chalk were filled with calcite.

In $90 \%$ of the studied thin-sections textures show that silicification was initiated in burrows; in the other $10 \%$, either organic-rich or iron-rich(?) layers served as loci for silicification, or secondary silica was distributed as random, diffuse patches within the chalk. The role of burrows as loci for silicification was also noted for DSDP Legs 5, 33, and 62 cores (Kelts, 1976; Hein et al., 1981). A detailed discussion of characteristics of silicified burrows is presented by Hein et al. (1981). Burrowsilica maturation is always a step ahead of host-rock silicification: in chalk, burrows are opal-CT or quartz; in porcellanite, burrows are quartz; and, in chert, bur- 
rows are coarser-grained quartz. Silica that fills microfossil chambers is also commonly more evolved diagenetically than silica in the host rock, so that the chalcedony or opal-CT that fills tests in the chalk contrasts with coarse-grained quartz test fillings in chert.

More-advanced silicification results in conversion of the first-formed opal-CT into interlocking grains of microcrystalline quartz, accompanied by loss of porosity (Plates 5, Figs. 1, 3, 4; 7, Fig. 2; 8, Figs. 5, 6). Foraminifers and radiolarians in the silica recrystallized, and are commonly recognized only because of slightly coarser grain size of their silica, whereas those in chalk were filled by opal-CT and quartz (Plate 7, Figs. 2, 5, 6) or replaced by silica. An opal-CT rim separates microcrystalline quartz from weakly silicified chalk, and is first encountered at a sub-bottom depth of 261 meters (Plate 8 , Figs. 5, 6). This rim, typical of most cherts recovered by DSDP, is the silicification front which will continue to replace adjacent chalk until the supply of silica is exhausted. Unlike chert from other DSDP legs, that from Leg 69 which has undergone the most advanced stages of silicification still contains recognizable foraminifers (Plate 7, Fig. 2). An advanced stage of silicification in which quartz recrystallized or grew by aggrading neomorphism destroyed foraminifers in other cherts (Hein et al., 1981), but this stage apparently was not reached in Leg 69 rocks.

Additional diagenetic features include pyritization, quartz and calcite remobilization, and compaction effects. Pyrite replaces microfossils in all studied lithologies of Site 504 (Plate 10, Figs. 3-5). Pyrite veins and stringers also are common (Plate 10, Fig. 6). Phosphatic debris is present in most rocks. Sub-millimeter-sized veins of quartz and calcite occur in places below 255 meters. Broken and squashed foraminifers occur with intact tests in numerous samples. Preferred orientation of elongate foraminifers and hematite and pyrite stringers occurs at $\mathbf{2 4 5}$ and 260 meters sub-bottom (Plate 8, Figs. 3, 4).

Diagenetic grade increases with increasing depth in the section. The first abundant quartz stringers occur at 246 meters, in the silicified chalks. Quartz-filled foraminifers in chalk first appear at about 246 meters, and become abundant by 260 meters, at which depth the walls of the foraminifers in chalk may be replaced by quartz. Below 255 meters, abundant hematite accompanies pyrite as an iron-bearing phase, whereas above this depth only pyrite is common. The first microgranular-quartz cherts appear at 255 meters and become well developed (lacking contamination by calcite) by 260 meters. These microcrystalline-quartz cherts contain the spherical radiolarian molds composed of coarser-grained quartz that typify radiolarian cherts elsewhere in the Pacific. Pervasive silicification of the chalk, characterized by abundant silica outside burrowed areas, begins near 260 meters sub-bottom and continues to basement. No greater degree of silicification/diagenesis is achieved.

\section{Geochemistry}

Chemical analyses were made for 19 rocks, including several rocks from which the carbonate fraction was removed (Table 3). Carbonate removal by $\mathrm{HCl}$ was performed in order to delineate the chemical changes that accompany the diagenetic transformation from chalk/ calcite to chert/quartz. In this context, calcite-rich rocks are classified as chalk, opal-CT-rich rocks as porcellanite, and quartz-rich rocks as chert. $\mathrm{SiO}_{2}$ increases on the average from $25 \%$ in chalk to $93 \%$ in porcellanite and $96 \%$ in chert. Accompanying the increase in $\mathrm{SiO}_{2}$ from chalk to chert is a decrease in most of the minor and trace elements, boron being a notable exception. Thus, our results suggest that volatiles (loss on fusion), $\mathrm{CaO}, \mathrm{Fe}_{2} \mathrm{O}_{3}, \mathrm{Zr}, \mathrm{V}, \mathrm{Sr}, \mathrm{Cr}, \mathrm{Y}, \mathrm{Zn}, \mathrm{FeO}, \mathrm{Ni}, \mathrm{Mn}, \mathrm{P}_{2} \mathrm{O}_{5}$, $\mathrm{Cu}, \mathrm{Co}$, and $\mathrm{Ba}$ decrease with increasing diagenesis. Carbonate rocks are not only distinguished by an expected high $\mathrm{CaO}$ content, but also by especially high values of $\mathrm{Mn}, \mathrm{Ba}, \mathrm{Sr}, \mathrm{Ni}, \mathrm{Zn}, \mathrm{Zr}, \mathrm{V}$, and $\mathrm{Co} . \mathrm{Cr}, \mathrm{Y}$, and $\mathrm{Zn}$ occur only in carbonate rocks. $\mathrm{Zr}, \mathrm{V}$, and $\mathrm{Sr}$ were detected in both carbonate and opal-CT rocks, but not in cherts. $\mathrm{Cu}$ is variable in all rock types. All rocks have low and comparable $\mathrm{Al}_{2} \mathrm{O}_{3}$ contents. Low $\mathrm{Al}_{2} \mathrm{O}_{3}$ and $\mathrm{TiO}_{2}$ contents preclude the presence of significant volcanic or terrigenous debris in the analyzed rocks. Thinsection observations support this conclusion.

Several elements display a continuous progression in three groups of porcellanites that contain increasing amounts of quartz, $(2,5$, and $10 \%$, respectively; Table 4). In addition, the opal-CT in the three groups of porcellanites shows decreasing $d$ spacings (increasingly ordered) with increasing quartz content. Thus, increasing order in opal-CT and increasing percentages of quartz in porcellanite are accompanied on the average by increases in $\mathrm{Na}_{2} \mathrm{O}, \mathrm{B}$, and $\mathrm{Co}$, and by decreases in volatiles, $\mathrm{Mn}, \mathrm{Ba}, \mathrm{Cu}$, and $\mathrm{Sr}$. Boron especially increases with increasing authigenic quartz, which supports the notion that B substitutes for $\mathrm{Si}$ in the quartz crystal structure during quartz precipitation (Hein et al., 1981). The high B content $(32 \mathrm{ppm})$ of the single analyzed chalk contrasts with that of chalks from the middle North Pacific (DSDP Leg 62), in which B was not detected (Hein et al., 1981). Pure chert (quartz) is characterized by high $\mathrm{SiO}_{2}$ and $\mathrm{B}$, and contains traces of other elements in smaller amounts than the other analyzed rock types. Overall, trace elements appear to decrease with increasing diagenetic grade, that is, with increasing silicification of the chalk.

Manganese, which increases with increasing depth, is the only element that changes consistently with subbottom depth within the major rock groups listed in Table 4. In general, $\mathrm{K}_{2} \mathrm{O}$ increases and $\mathrm{Ba}$ decreases in porcellanites with increasing depth. $\mathrm{Ba}$, however, may increase in carbonate rocks with increasing depth. The $\mathrm{Mn}$ and $\mathrm{K}_{2} \mathrm{O}$ trends probably reflect proximity to basaltic basement, their probable source. $\mathrm{Ba}$, on the other hand, probably has a biogenic source, although $\mathrm{Ba}$ also can have hydrogenous and hydrothermal sources (Heath and Dymond, 1977).

Leg 69 cherts, when the small amount of $\mathrm{CaCO}_{3}$ is removed by $\mathrm{HCl}$, are chemically very pure, averaging over $96 \% \mathrm{SiO}_{2}$. This compares with the $95 \%$ average $\mathrm{SiO}_{2}$ for Pacific DSDP Leg 62 noncalcareous cherts, and contrasts with many Atlantic cherts that contain up 
Table 3. Chemical analyses of chert, porcellanite, and chalk, DSDP Leg 69, in percent (oxides) and ppm (minor elements).

\begin{tabular}{|c|c|c|c|c|c|c|c|c|c|c|}
\hline Component & $504-53-1,10-14^{*}$ & $\begin{array}{l}504-53-1,21-23 \\
\text { (bulk) }\end{array}$ & 504A-1,CC* & $\begin{array}{l}504 \mathrm{~A}-2, \mathrm{CC} \\
\text { (bulk) }\end{array}$ & $504 \mathrm{~A}-2, \mathrm{CC}^{*}$ & $504 \mathrm{~A} \cdot 3-1,59-61^{*}$ & $504 \mathrm{~A}-3-1,100-103^{\circ}$ & $504 \mathrm{~A}-3-1,103-106^{\circ}$ & $504 \mathrm{~A}-4-1,81-84^{\circ}$ & $504 \mathrm{~A}-4-1,110-112^{*}$ \\
\hline $\mathrm{SiO}_{2}(\%)$ & 90.81 & 24.6 & 92.59 & 37.0 & 92.51 & 93.24 & 92.42 & 95.19 & 92.12 & 95.93 \\
\hline $\mathrm{Al}_{2} \mathrm{O}_{3}$ & 0.91 & 2.0 & 1.08 & 1.6 & 1.48 & 0.93 & 0.88 & 0.88 & 1.39 & 1.17 \\
\hline $\mathrm{TiO}_{2}$ & $<0.01$ & $<0.01$ & $<0.01$ & $<0.01$ & $<0.01$ & $<0.01$ & $<0.01$ & $<0.01$ & $<0.01$ & $<0.01$ \\
\hline $\mathrm{Fe}_{2} \mathrm{O}_{3}$ & 0.19 & 0.37 & 0.17 & 0.14 & 0.16 & 0.18 & 0.18 & 0.04 & 0.22 & 0.00 \\
\hline $\mathrm{FeO}$ & 0.13 & 0.20 & 0.15 & 0.14 & 0.14 & 0.12 & 0.12 & 0.12 & 0.23 & 0.12 \\
\hline $\mathrm{MgO}$ & $<0.2$ & $<0.2$ & $<0.2$ & $<0.2$ & 0.3 & $<0.2$ & $<0.2$ & $<0.2$ & 0.4 & $<0.2$ \\
\hline $\mathrm{CaO}$ & $<0.01$ & 28.9 & $<0.01$ & 24.8 & $<0.01$ & $<0.01$ & 0.09 & $<0.01$ & 0.04 & $<0.01$ \\
\hline $\mathrm{Na}_{2} \mathrm{O}$ & 0.93 & 4.6 & 0.88 & 3.8 & 0.99 & 0.96 & 1.02 & 1.11 & 1.05 & 1.04 \\
\hline $\mathrm{K}_{2} \mathrm{O}$ & 0.07 & 0.2 & 0.07 & 0.1 & 0.08 & 0.08 & 0.07 & 0.06 & 0.14 & 0.05 \\
\hline $\mathrm{P}_{2} \mathrm{O}_{5}$ & $<0.01$ & 0.3 & $<0.01$ & 0.3 & $<0.01$ & $<0.01$ & $<0.01$ & $<0.01$ & $<0.01$ & $<0.01$ \\
\hline LOF*• & 6.74 & 32.4 & 4.36 & 28.88 & 4.49 & 4.74 & 4.49 & 3.60 & 4.62 & 1.73 \\
\hline Total & 99.78 & 93.58 & 99.30 & 96.76 & 100.15 & 100.25 & 99.27 & 101.00 & 100.21 & 100.04 \\
\hline Mn (ppm) & 108 & 1394 & 93 & 1084 & 108 & 85 & 108 & 124 & 132 & 170 \\
\hline $\mathrm{Ag}$ & $<1$ & $<1$ & $<1$ & $<1$ & $<1$ & $<1$ & $<1$ & $<1$ & $<1$ & $<1$ \\
\hline B & $<10$ & 32 & 21 & $<10$ & 18 & 25 & 18 & 21 & 11 & 41 \\
\hline $\mathrm{Ba}$ & 1500 & 1800 & 1500 & 1400 & 1300 & 630 & 670 & 150 & 2700 & 170 \\
\hline $\mathrm{Co}$ & $<1.0$ & 8.7 & 1.4 & 5.7 & 1.1 & 2.7 & 2.3 & 2.3 & $<1.0$ & 1.6 \\
\hline $\mathrm{Cr}$ & $<10$ & 11 & $<10$ & $<10$ & $<10$ & $<10$ & $<10$ & $<10$ & $<10$ & $<10$ \\
\hline $\mathrm{Cu}$ & 35 & 32 & 30 & 22 & 31 & 24 & 22 & 18 & 35 & 9.2 \\
\hline $\mathrm{Ni}$ & 7.8 & 32 & 8.5 & 16 & 10 & 13 & 13 & 14 & 9.7 & 4.5 \\
\hline $\mathrm{Sr}$ & 48 & 1000 & 42 & 700 & 43 & 19 & 23 & $<10$ & 75 & $<10$ \\
\hline v & $<10$ & 27 & 15 & 15 & $<10$ & 15 & 14 & $<10$ & 16 & $<10$ \\
\hline $\mathbf{Y}$ & $<10$ & 16 & $<10$ & 12 & $<10$ & $<10$ & $<10$ & $<10$ & $<10$ & $<10$ \\
\hline $\mathrm{Zn}$ & $<50$ & 150 & $<50$ & $<50$ & $<50$ & $<50$ & $<50$ & $<50$ & $<50$ & $<50$ \\
\hline $\mathrm{Zr}$ & 28 & 58 & 27 & 50 & 39 & 20 & 22 & $<20$ & 34 & $<20$ \\
\hline Lithology & $\begin{array}{l}\text { Greenish-tan, } \\
\text { calcareous } \\
\text { opal-CT chert }\end{array}$ & $\begin{array}{l}\text { White, siliceous } \\
\text { chalk }\end{array}$ & $\begin{array}{l}\text { Greenish- } \\
\text { tan, cal- } \\
\text { careous } \\
\text { porcellanite }\end{array}$ & $\begin{array}{l}\text { White, } \\
\text { partly silic- } \\
\text { ified chalk }\end{array}$ & $\begin{array}{l}\text { Gray, cal- } \\
\text { careous por- } \\
\text { cellanite }\end{array}$ & $\begin{array}{l}\text { Greenish-brown, } \\
\text { calcareous chert }\end{array}$ & $\begin{array}{l}\text { Grayish-brown, cal- } \\
\text { careous chert and } \\
\text { porcellanite }\end{array}$ & $\begin{array}{l}\text { Gray-brown, } \\
\text { chert-casts of } \\
\text { burrows }\end{array}$ & $\begin{array}{l}\text { Gray, calcareous } \\
\text { porcellanite }\end{array}$ & $\begin{array}{l}\text { Slightly calcareous, } \\
\text { brown chert }\end{array}$ \\
\hline
\end{tabular}

Note: Other elements were scanned, but are below these limits of detection in ppm: Be (1.0), Ca (10), Ce (100), Ga (10), La (20), Li (50), Mo (10), Mb (25),

- Treated with $\mathrm{HCl}$ to remove calcite.

$\because$ Loss on fusion at $1050^{\circ} \mathrm{C}$

*** major oxides and minor elements from emission spectroscopy: total $\mathrm{Fe}$ calculated as $\mathrm{Fe}_{2} \mathrm{O}_{3}$.

to $40 \%$ clay (Berger and von Rad, 1972). Chemical data support the concept of genesis of cherts by progressive replacement of carbonate rocks by silica. During this replacement, most elements were rejected from the host rocks, except boron, which was incorporated into the precipitated-quartz crystal lattice. Although manganese content is highly variable among major rock types, it increases toward basaltic basement within a single rock type; thus, the signature of the parent rock's position relative to basement is preserved through the complete diagenetic sequence. Terrigenous and volcanic debris either were not originally present in these silicified rocks or were replaced or displaced during silicification.

\section{DISCUSSION}

\section{Geochemistry, Comparison with Leg 62 Rocks}

Some interesting comparisons between Leg 62 and Leg 69 cherts may provide insight into environments of deposition of cherts. Leg 62 rocks formed on oceanic plateaus (Mid-Pacific Mountains, Hess Rise) distant from land in the central North Pacific. Leg 69 rocks formed near an active oceanic spreading center adjacent to Central and South America. In general, the chemical elements typically associated, at least in part, with hydrothermal activity at spreading centers are more abundant in silicified rocks from Leg 69 than from Leg 62. $\mathrm{Mn}, \mathrm{Cu}, \mathrm{Ni}, \mathrm{Co}, \mathrm{Zr}, \mathrm{Ba}$, and $\mathrm{V}$ are much less abundant in Leg 62 carbonate rocks and silicified rocks, whereas $\mathrm{Cr}, \mathrm{B}, \mathrm{Y}, \mathrm{TiO}_{2}, \mathrm{MgO}$, and $\mathrm{Fe}_{2} \mathrm{O}_{3}$ are greater in Leg 62 rocks. We interpret these differences as follows: (1) Leg 62 rocks reflect greater contamination by basaltic debris, as indicated by high and more consistently occurring $\mathrm{Cr}$ and $\mathrm{TiO}_{2}$ (Hein et al., 1981); (2) Leg 69 rocks reflect formation near a spreading center, as suggested by high $\mathrm{Mn}, \mathrm{Cu}$, and perhaps $\mathrm{Ba}$ contents; $\mathrm{Zn}$, occurring only in Leg 69 chalks, may also reflect a hydrothermal source; (3) Leg 62 cherts (quartz) precipitated more slowly under open-ocean conditions, as indicated by the much higher boron content ( 75 versus $35 \mathrm{ppm}$ ); (4) the greater $\mathrm{MgO}$ in Leg 62 rocks than in Leg 69 rocks, especially in the chalks, may reflect $\mathrm{Mg}$ substitution in the secondary calcite, the $\mathrm{Mg}$ being derived from greater submarine weathering of the ancient oceanic crust forming the plateaus.

$\mathrm{Al}_{2} \mathrm{O}_{3}, \mathrm{Fe}_{2} \mathrm{O}_{3}$, and $\mathrm{Mn}$ are especially interesting because they have been used as possible representatives of near-continent versus open-ocean depositional environments for chert in a pioneering study by Steinberg and Marin (1978); these authors used various combinations and ratios of $\mathrm{Al}, \mathrm{Fe}, \mathrm{Mg}$, and $\mathrm{Mn}$ to discriminate between mid-ocean-ridge and continental-margin environments, and by extrapolation they inferred that openocean environments are intermediate to these two end members. In general, the open-ocean Leg 62 rocks contain slightly less $\mathrm{Al}_{2} \mathrm{O}_{3}$ than Leg 69 rocks $(0.69$ versus $1.07 \%$ ). Three Leg 62 rocks, however-two tuffaceous cherts and a calcareous porcellanite-have more than $7 \% \mathrm{Al}_{2} \mathrm{O}_{3}$. Similar $\mathrm{Al}_{2} \mathrm{O}_{3}$-rich siliceous rocks were not found in the near-continent Leg 69 section. Aluminum in the open ocean was derived locally from volcanic debris, or from distant continental areas by eolian transport. Similarly, $\mathrm{Fe}_{2} \mathrm{O}_{3}$ and $\mathrm{Mn}$ may not reflect position of deposition relative to a continent; rather, high $\mathrm{Mn}$ or $\mathrm{Mn}+\mathrm{Fe}$ probably indicates formation near an active spreading center (Steinberg and Marin, 1978), regardless of whether the spreading center is adjacent to or distant from a continent. It should be emphasized, however, that $\mathrm{Mn}$ is one of the most highly variable elements studied, and many diagenetic as well as primary deposi- 
Table 3. (Continued).

\begin{tabular}{|c|c|c|c|c|c|c|c|c|}
\hline $\begin{array}{l}504 \mathrm{~A}-4-1,110-112 \\
\text { (bulk) }\end{array}$ & $\begin{array}{l}\text { 504A-5-1, 8-12 } \\
\text { (bulk) }\end{array}$ & $504 \mathrm{~A}-5-1,37-39^{*}$ & $\begin{array}{l}\text { 504A-5-1, 75-78 } \\
\text { (bulk) }\end{array}$ & $\begin{array}{c}504 \mathrm{~A} \cdot 5-1,75-78 \\
\text { (2) }^{*}\end{array}$ & $\begin{array}{c}504 \mathrm{~A}-5-1,75-78 \\
(1)^{6}\end{array}$ & $\begin{array}{c}504 \mathrm{~B}-1-1,63-68 \\
(1)^{*}\end{array}$ & $\begin{array}{c}\text { 504B-1-1, 63-68 } \\
\text { (bulk) }\end{array}$ & $\begin{array}{c}504 \mathrm{~B}-1-1,63-68 \\
(2)^{*}\end{array}$ \\
\hline 92.75 & 43.8 & 96.50 & 68.46 & $>85 * *$. & $>85^{*} \cdots$ & 92.52 & 78.96 & 91.61 \\
\hline 1.14 & 1.9 & 1.16 & 1.24 & 0.85 & 0.96 & 0.90 & 1.07 & 0.87 \\
\hline$<0.01$ & $<0.01$ & $<0.01$ & $<0.01$ & $<0.03$ & $<0.03$ & 0.05 & $<0.01$ & $<0.01$ \\
\hline 0.02 & 0.47 & 0.03 & 0.13 & 0.20 & 0.14 & 0.10 & 0.01 & 0.003 \\
\hline 0.10 & 0.30 & 0.13 & 0.12 & - & - & 0.13 & 0.15 & 0.15 \\
\hline$<0.2$ & 1.3 & 0.3 & 0.4 & $<0.17$ & $<0.17$ & $<0.2$ & $<0.2$ & $<0.2$ \\
\hline 1.73 & 22.1 & 0.05 & 14.2 & $<0.07$ & $<0.07$ & $<0.01$ & 7.87 & $<0.01$ \\
\hline 1.12 & 3.5 & 1.09 & 1.36 & $<0.2$ & $<0.2$ & $<0.01$ & 1.66 & 1.08 \\
\hline 0.05 & 0.2 & 0.07 & 0.10 & $<0.10$ & $<0.10$ & 1.20 & 0.05 & 0.04 \\
\hline 0.03 & 0.2 & $<0.01$ & 0.11 & $<0.05$ & $<0.05$ & $<0.01$ & 0.05 & 0.01 \\
\hline 3.21 & 24.26 & 1.94 & 13.67 & - & - & 5.43 & 10.74 & 5.74 \\
\hline 100.15 & 98.03 & 101.27 & 99.79 & - & - & 100.33 & 100.56 & 99.50 \\
\hline 225 & 1472 & 178 & 1131 & 200 & $<200$ & 201 & 395 & 155 \\
\hline$<1$ & $<1$ & $<1$ & $<1$ & $<1$ & $<1$ & $<1$ & 8.0 & $<1$ \\
\hline 34 & $<10$ & 25 & $<10$ & 29 & 35 & 11 & $<10$ & 13 \\
\hline 210 & 2500 & 130 & 1000 & 37 & 50 & 1200 & 680 & 830 \\
\hline 1.9 & 9.4 & 1.9 & 3.9 & 1.5 & 1.4 & 1.2 & 2.0 & 2.6 \\
\hline$<10$ & 11 & $<10$ & $<10$ & $<10$ & $<10$ & $<10$ & $<10$ & $<10$ \\
\hline 12 & 41 & 14 & 73 & 13 & 28 & 23 & 15 & 17 \\
\hline 5.4 & 31 & 7.9 & 16 & 9.4 & 8.3 & 5.4 & 8.4 & 5.7 \\
\hline 14 & 670 & $<10$ & 380 & $<10$ & $<10$ & 31 & 240 & 24 \\
\hline$<10$ & 25 & $<10$ & 11 & $<10$ & $<10$ & $<10$ & $<10$ & 15 \\
\hline$<10$ & 16 & $<10$ & $<10$ & $<10$ & $<10$ & $<10$ & $<10$ & $<10$ \\
\hline$<50$ & 57 & $<50$ & $<50$ & $<30$ & $<50$ & $<50$ & $<50$ & $<50$ \\
\hline$<20$ & 52 & $<20$ & 28 & $<20$ & $<20$ & 20 & 21 & 21 \\
\hline $\begin{array}{l}\text { Slightly } \\
\text { calcareous, brown } \\
\text { chert }\end{array}$ & $\begin{array}{l}\text { White, partly } \\
\text { silicified chalk } \\
\text { and gray } \\
\text { calcareous } \\
\text { porcellanite } \\
\text { and chert }\end{array}$ & $\begin{array}{l}\text { Very dark-brown } \\
\text { chert }\end{array}$ & $\begin{array}{l}\text { Light-gray } \\
\text { calcareous } \\
\text { porcellanite }\end{array}$ & $\begin{array}{l}\text { Gray-brown } \\
\text { chert }\end{array}$ & $\begin{array}{l}\text { Véry dark- } \\
\text { brown chert }\end{array}$ & $\begin{array}{l}\text { Grayish-brown, } \\
\text { calcareous } \\
\text { porcellanite }\end{array}$ & $\begin{array}{l}\text { Burrowed, } \\
\text { calcareous } \\
\text { porcellanite }\end{array}$ & $\begin{array}{l}\text { Chert burrows } \\
\text { in calcareous } \\
\text { porcellanite }\end{array}$ \\
\hline
\end{tabular}

Table 4. Average compositions and standard deviations (parentheses) for rock types presented in Table 3, in percent (oxides) and ppm (minor elements).

\begin{tabular}{|c|c|c|c|c|c|c|c|c|c|c|c|c|c|c|}
\hline \multirow{2}{*}{$\frac{\text { Component }}{\mathrm{SiO}_{2}(\%)}$} & \multicolumn{2}{|c|}{$\begin{array}{l}\text { Chert: } \\
\text { Quartz }\end{array}$} & \multirow{2}{*}{$\begin{array}{c}\text { Chert: } \\
\text { Quartz, } \\
\text { Trace } \\
\text { Calcite }\end{array}$} & \multicolumn{2}{|c|}{$\begin{array}{l}\text { Porcellanite: } \\
\text { Opal-CT and } \\
\sim 15 \% \text { Quartz }\end{array}$} & \multicolumn{2}{|c|}{$\begin{array}{l}\text { Porcellanite: } \\
\text { Opal-CT and } \\
\sim 5 \% \text { Quartz }\end{array}$} & \multicolumn{2}{|c|}{$\begin{array}{l}\text { Porcellanite: } \\
\text { Opal-Ct and } \\
\sim 2 \% \text { Quartz }\end{array}$} & \multicolumn{2}{|c|}{$\begin{array}{l}\text { Calcareous Por- } \\
\text { cellanite: Cal- } \\
\text { cite, Opal-CT, } \\
\text { Minor Quartz }\end{array}$} & \multicolumn{2}{|c|}{$\begin{array}{c}\text { Partly Silicified } \\
\text { Chalk: } \\
\text { Calcite, } \\
\text { Opal-CT }\end{array}$} & \multirow{2}{*}{$\begin{array}{c}\text { Siliceous } \\
\text { Chalk: } \\
\text { Calcite, } \\
\text { Opal-A }\end{array}$} \\
\hline & 96.22 & $(0.40)$ & & 93.62 & $(1.42)$ & 92.10 & $(0.69)$ & 91.99 & $(0.81)$ & 73.71 & $(7.42)$ & 40.40 & $(4.81)$ & \\
\hline $\begin{array}{l}\mathrm{Al}_{2} \mathrm{O}_{3} \\
\mathrm{TiO}_{2}\end{array}$ & 1.10 & $(0.12)$ & 1.14 & 0.89 & $(0.03)$ & 0.98 & $(0.15)$ & $\begin{array}{l}1.17 \\
0.01\end{array}$ & $\begin{array}{l}(0.31) \\
(0.03)\end{array}$ & 1.16 & $(0.12)$ & 1.75 & $(0.21)$ & 2.0 \\
\hline $\mathrm{Fe}_{2} \mathrm{O}_{3}$ & 0.02 & $(0.02)$ & 0.02 & 0.13 & $(0.08)$ & 0.09 & $(0.12)$ & 0.17 & $(0.05)$ & 0.07 & $(0.08)$ & 0.31 & $(0.23)$ & 0.37 \\
\hline $\mathrm{FeO}$ & 0.13 & $(0.01)$ & 0.10 & 0.12 & $(0.00)$ & 0.15 & $(0.00)$ & 0.16 & $(0.05)$ & 0.14 & $(0.02)$ & 0.22 & $(0.11)$ & 0.20 \\
\hline $\mathrm{MgO}$ & 0.10 & $(0.17)$ & & & & & & 0.18 & $(0.21)$ & 0.20 & $(0.28)$ & 0.65 & $(0.92)$ & \\
\hline $\mathrm{CaO}$ & 0.02 & $(0.03)$ & 1.73 & 0.02 & $(0.05)$ & & & 0.01 & $(0.02)$ & 11.04 & (4.48) & 23.45 & (1.91) & 28.9 \\
\hline $\mathrm{Na}_{2} \mathrm{O}_{3}$ & 1.07 & $(0.04)$ & 1.12 & 1.03 & $(0.08)$ & 0.98 & $(0.14)$ & 0.74 & $(0.50)$ & 1.51 & $(0.21)$ & 3.65 & $(0.21)$ & 4.6 \\
\hline $\mathrm{K}_{2} \mathrm{O}$ & 0.06 & $(0.01)$ & 0.05 & 0.07 & $(0.01)$ & 0.05 & $(0.02)$ & 0.37 & $(0.55)$ & 0.08 & $(0.04)$ & 0.15 & $(0.07)$ & 0.2 \\
\hline $\mathrm{P}_{2}^{2} \mathrm{O}_{5}$ & & & 0.03 & & & 0.01 & $(0.01)$ & & & 0.08 & $(0.04)$ & 0.25 & $(0.07)$ & 0.3 \\
\hline LOF** & 1.84 & $(0.15)$ & 3.21 & 4.28 & $(0.60)$ & 5.05 & $(0.98)$ & 5.32 & $(1.03)$ & 12.21 & (2.07) & 26.57 & (3.27) & 32.4 \\
\hline $\begin{array}{l}\text { Mn (ppm) } \\
\mathrm{Ag}\end{array}$ & 174 & (5.7) & 225 & 106 & (19.6) & 124 & $(43.8)$ & 137 & $(44.0)$ & $\begin{array}{l}763 \\
4.0\end{array}$ & $\begin{array}{l}(520) \\
(5.7)\end{array}$ & 1278 & (274) & 1394 \\
\hline B & 34 & (8.1) & 34 & 23 & $(4.8)$ & 17 & (5.7) & 10 & $(7.4)$ & & & & & 32 \\
\hline $\mathrm{Ba}$ & & (61.1) & 210 & 372 & $(325)$ & 1165 & (474) & 1675 & (695) & 840 & (226) & 1950 & (778) & 1800 \\
\hline Co & 1.6 & $(0.3)$ & 1.9 & 2.2 & $(0.5)$ & 2.0 & $(0.8)$ & 0.58 & $(0.7)$ & 3.0 & (1.3) & 7.6 & (2.6) & 8.7 \\
\hline $\mathrm{Cr}$ & & & & & & & & & & & & 6 & $(7.8)$ & 11 \\
\hline $\mathrm{Cu}$ & 17 & (9.8) & 12 & 19 & (4.9) & 24 & $(9.2)$ & 31 & (5.7) & 44 & $(41.0)$ & 32 & (13.4) & 32 \\
\hline $\mathrm{Ni}$ & 6.9 & (2.1) & 5.4 & 12 & (2.0) & 7.1 & $(2.0)$ & 8.2 & (2.1) & 12 & $(5.4)$ & 24 & (10.6) & 32 \\
\hline $\mathrm{Sr}$ & & & 14 & 111 & (12.2) & 33 & (12.7) & 49 & (18.6) & 310 & (99) & 685 & (21) & 1000 \\
\hline V & & & & 7 & $(8.4)$ & 15 & $(0.0)$ & 4 & $(8.0)$ & 6 & (7.8) & 20 & (7.1) & 27 \\
\hline Y & & & & & & & & & & & & 14 & (2.8) & 16 \\
\hline $\mathrm{Zn}$ & & & & & & & & & & & & 29 & $(40)$ & 150 \\
\hline $\mathrm{Zr}$ & & & & 11 & (12.2) & 24 & (4.2) & 30 & $(8.2)$ & 25 & (4.9) & 51 & (1.4) & 58 \\
\hline \multicolumn{15}{|l|}{ No. of } \\
\hline $\begin{array}{l}\text { Counting } \\
\text { from Left } \\
\text { in Table } 3\end{array}$ & \multicolumn{2}{|c|}{$10,13,16$} & 11 & \multicolumn{2}{|c|}{$6,7,8,15$} & \multicolumn{2}{|c|}{3,19} & \multicolumn{2}{|c|}{$1,5,9,17$} & \multicolumn{2}{|c|}{14,18} & \multicolumn{2}{|c|}{4,12} & 2 \\
\hline
\end{tabular}

* Loss on fusion at $1050^{\circ} \mathrm{C}$.

tional processes may influence Mn distribution. Our results suggest that $\mathrm{Fe}_{2} \mathrm{O}_{3}$ is most indicative of the pelagic realm, since the highest values are from chert that replaced pelagic clay (Hein et al., 1981). Again, caution is necessary, because high $\mathrm{Fe}_{2} \mathrm{O}_{3}$ values can also accom- pany contamination of the chert by oceanic volcanic debris (Hein et al., 1981).

These associations should not be applied without other supporting evidence to determine depositional environments for cherts from other locations. Many more 
samples and rigorous statistical studies are necessary before general rules on chemical signatures of depositional environments can be formulated. These data simply point to possibilities and indicate that caution should be used in attributing environmental significance to $\mathrm{Al}$, $\mathrm{Mn}$, and Fe (see also Steinberg and Marin, 1978).

\section{Petrogenesis}

The sequential development of chert from siliceous carbonate was presented in detail by Heath and Moberly (1971) and Keene $(1975,1976)$, and was expanded and modified somewhat by Hein et al. (1981). Opal-A (biogenic silica) is the major source of silica for chert and porcellanite. Clay minerals and volcanic debris may be important local sources of silica (Keene and Kastner, 1974; Pisciotto, 1980), but there is no evidence for this in Leg 69 deposits. Silicification appears to have been initiated once the appropriate temperature was reached to convert the opal-A in the chalk to opal-CT. This temperature most commonly ranges from $30^{\circ}$ to $50^{\circ} \mathrm{C}$ (Hein et al., 1978). Development of chert was basically a four-step process (Hein et al., 1981). First, tests of foraminifers and radiolarians and burrows were filled predominantly with opal-CT, which was subsequently converted in the tests to chalcedonic quartz and microgranular quartz in a relatively short time. Second, the nannofossil-foraminifer host carbonate was partly cemented and replaced by opal-CT. Silicified nannofossils commonly were preserved after the opal-CT inverted to quartz, apparently by solid-solid reaction. Burrows were commonly the loci of initial silicification which spread out from these centers. At this stage, the rock was still very porous. Third, the opal-CT converted to quartz, probably by solution-precipitation, producing porous quartz porcellanite. Fourth, vitreous, dense chert formed by recrystallization and crystal growth of the quartz.

Many aspects of the Leg 69 rocks differ from the general sequence just outlined. In Leg 69 rocks, the fourth stage was achieved only in burrows. Because of the high heat flow and rapid and incomplete silicification at Site 504, rocks of the third stage are mixtures of opal-CT and quartz. The high porosity of most Leg 69 silicified rocks results from incomplete silicification. In turn, incomplete silicification results either from insufficient primary silica (opal-A) in the host chalk, from insufficient time for aging (maturation) of the beds, or from too-rapid silicification which did not allow time for migration and concentration of silica.

Silicification first appears in upper Miocene deposits, indicating at least a 5-m.y. lag from deposition to diagenesis. The stages of diagenesis outlined above took about $1 \mathrm{~m} . \mathrm{y}$. to complete, a time interval bounded by the 6.2-m.y. age of the basaltic basement and the age of the youngest chert, about $5.2 \mathrm{~m}$.y. This supports the suggestion of Hein et al. (1981) that once silicification begins in deep-sea deposits it progresses rapidly, taking possibly only a few millions of years to complete. The time needed to complete silicification contrasts with the maximum of 30 to 90 m.y. required for silicification to be initiated in most open-ocean deposits (Keene, 1975; Pisciotto, 1980; Hein et al., 1981).
Silica diagenesis of diatomaceous deposits in the Bering Sea began, as with Leg 69 deposits, after about a 5 -m.y. time lag, but required 450 to 550 meters of burial, in contrast to only 225 meters at Site 504 (Hein et al., 1978). Regardless of the thickness of overburden, Bering Sea conversions of opal-A to opal-CT occurred at temperatures that ranged from $35^{\circ}$ to $50^{\circ} \mathrm{C}$ (Hein et al., 1978). Temperatures of conversion for Leg 69 silica polymorphs were at the high end of the range determined for the Bering Sea samples, that is about $50^{\circ} \mathrm{C}+$ (Becker et al., this volume). The relationship of temperature to silica diagenesis is discussed in detail by Hein and Yeh (this volume). The time and temperature of transformation of opal-A to opal-CT for Leg 69 falls at the upper limit of the field defined by other studies (Hein et al., 1978; Fig. 5). Conditions of silicification at Site 504 more closely approximated those that occur at continental margins with respect to time and temperature of transformation, but are more similar to openocean deposits with respect to sedimentation rates and depths of burial (Fig. 5).

An important difference between the Bering Sea and Leg 69 sections is the formation of secondary quartz in the latter, but not in the Bering Sea sections. In fact, Leg 69 recovered one of the youngest known occurrences of quartz cherts. The very high heat flow apparently forced the conversion of opal-CT to quartz even before very much ordering of the opal-CT occurred. Opal-CT commonly orders from 4.12 to 4.07 or $4.04 \AA$ before conversion to quartz (Murata and Lar-

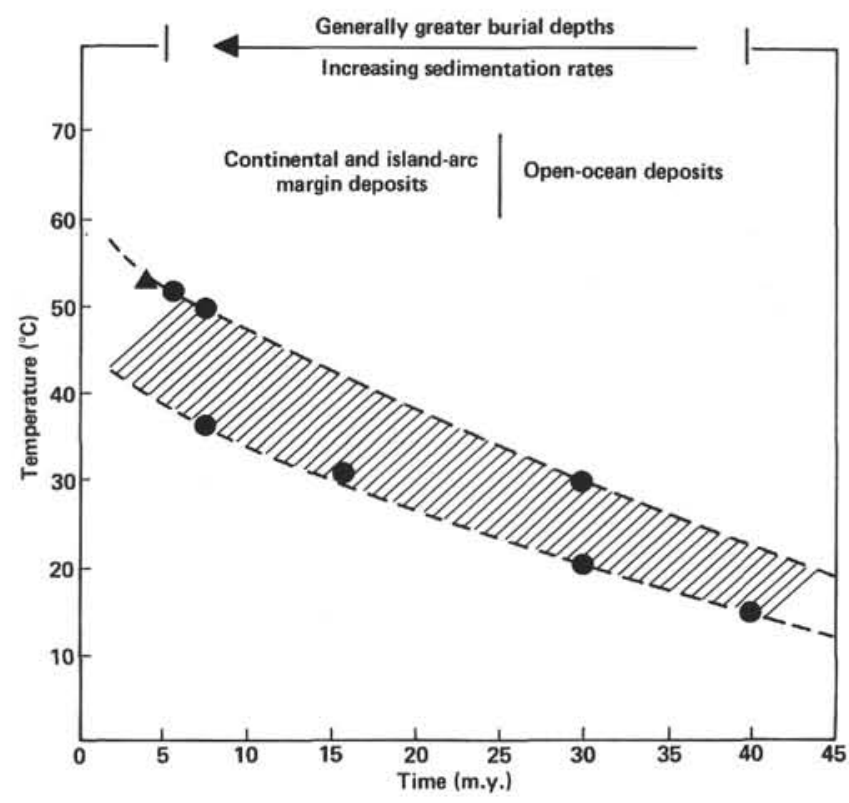

Figure 5. Estimated field of times and temperatures necessary for initiation of the transformation of opal-A to opal-CT. Reproduced from Hein et al. (1978), with addition of a point from this study (triangle), and a point at $16 \mathrm{~m} . \mathrm{y}$. and $31^{\circ} \mathrm{C}$ from a recent study by Moore and Gieskes (1980). Other points are based on data from the Bering Sea, Monterey Formation, and some North Pacific chert and porcellanite occurrences from Heath and Moberly (1971), Heath (1973), Lancelot (1973), von Rad and Rosch (1974), and Murata et al. (1977). 
son, 1975; Pisciotto, 1978; Hein et al., 1981). The high heat flow also caused crystallization of opal-CT in a highly disordered state, that is, with a wide range of $d$ spacings up to $4.131 \AA$ - compared with a $4.120 \AA$ value obtained by other workers (Murata and Larson, 1975; Hein et al., 1978, 1981; Pisciotto, 1978, 1980).

\section{Influences of Sediment Inhomogeneities on Silicification}

Two characteristics of the primary sediment influence to a large degree the patterns of silicification. Burrows, in part, control the loci of silicification and silica migration (Hein et al., 1981; Kelts, 1976), whereas the original amount and types of biogenic silica in the sediment control the degree and perhaps, in part, the initial stratigraphic level of silicification.

Burrowing appears to be extensive and pervasive in the chalks (Beiersdorf and Natland, this volume). Consequently, it is difficult to understand how burrowing might control the location of silicification. Close inspection of weakly silicified Cores 50 through 53 , however, reveals patterns in the burrowing. Although the cores essentially are completely burrowed, the burrowing differs in intensity and in types of burrows between adjacent layers, the layers being mostly less than $20 \mathrm{~cm}$ thick. Sparsely burrowed layers are adjacent to extensively burrowed ones; layers containing many or mostly large-ringed Zoophycos burrows are adjacent to ones containing only small Chondrites. It is beyond the scope of this work to decipher the burrow combinations most likely to attract silicification, but we assume that the greater the porosity created by burrowing, the greater the chance of silicification. All pure quartz cherts are casts of large burrows, probably Cylindrichnus or Planolites. The importance of burrowing in controlling the loci of silicification has been recognized only recently (Kelts, 1976; Hein et al., 1981); delineation of the details of the processes, however, will require the participation of an expert on trace fossils.

Biogenic-silica content and microfossil types also influence silicification. The chalk-chert-limestone sequence, deposited during the latest Miocene (5-6.2 Ma) as a biogenic ooze, is composed mostly of calcareous nannofossils and diatoms, with lesser amounts of planktonic foraminifers and radiolarians. Judging by other equatorial Pacific DSDP sites $(83,157,158,166,503)$ the latest Miocene was a time of very high biogenic productivity, when diatoms of the Thalassionema group were especially common (see Sancetta, this volume). At Site 504, and elsewhere, productivity of siliceous microfossils decreased sharply in the earliest Pliocene.

At Site 503, about $1000 \mathrm{~km}$ west of Site 504, upper Miocene sediment shows cycles of better and poorer preservation of calcium carbonate, presumably due to changes in bottom-water chemistry (Gardner, in press). The result is that alternate layers of the sediment are more or less enriched in silica relative to calcium carbonate. The silica-rich intervals are almost a Thalassionema ooze (Sancetta, in press). Thalassionema are elongate, needle-like forms with a large surface area, and not particularly resistant to dissolution (Mikkelsen,
Naja, Københavns Universitet, pers. comm.). Layers enriched in Thalassionema have high porosity (sediments at Site 503 are under-compacted; Mayer, in press), and a large amount of relatively soluble silica is available (Plate 13, Fig. 1), whereas layers enriched in calcium carbonate are more dense, with closely packed calcareous nannofossils and lesser amounts of silica (Plate 13, Fig. 2).

If the Miocene sediment at Site 504 were originally similar to that at Site 503-as implied by the high numbers of Thalassionema in 504-52, CC and 504-53,CCthen diagenesis would have created alternate layers of chert/porcellanite and siliceous chalk/limestone. Poor recovery in this lowermost interval at Site 504 (typically less than $40 \%$ ) makes it difficult to determine the true stratification, but the down-hole televiewer (Anderson and Zoback, this volume) indicates several beds in the chalk-chert-limestone sequence that could be interpreted as alternate chert and limestone. That a Thalassionema ooze can be a source of deep-sea chert is suggested by a photograph of a thin-section of Pleistocene(?) chert from the Indian Ocean (Schrader, 1974; Plate 13), which shows a Thalassionema ooze grading downward into chert.

If these hypotheses are correct, then studies of finescale chertification must consider possible inhomogeneities in the source sediment, resulting from fluctuations in productivity, preservation of microfossils, and patterns of burrowing. Pliocene sediment at Site 504, now chalk or siliceous nannofossil ooze, may not produce chert, in the strict sense, during future diagenesis. The amount of silica (diatoms) is too little in this section to produce chert; rather, a partly silicified chalk should be produced.

\section{SUMMARY AND CONCLUSIONS}

Chert and porcellanite formed by cementation and volume-for-volume replacement of carbonate host rocks. The 10 to $35 \%$ radiolarians and diatoms in the host chalks dissolved when the temperature in the sediment column reached about $50^{\circ}$ to $55^{\circ} \mathrm{C}$, and after $225 \mathrm{me}-$ ters of burial. The dissolved biogenic silica precipitated rapidly as opal-CT in places of greatest porosity. The initial loci of precipitation were burrows and microfossil tests, particularly foraminifers. As a result of low abundances of original opal-A and rapid dissolution and reprecipitation, silicification was patchy and incomplete. Silicified rocks commonly contain much included carbonate debris. Secondary quartz formed from opal-CT at a temperature near $55^{\circ} \mathrm{C}$ after 230 meters of burial, but quartz did not become abundant until after about 255 to 260 meters of burial, corresponding to temperatures of about $55^{\circ}$ to $60^{\circ} \mathrm{C}$. Typical temperatures reported in the literature for transformations of opal-A to opal-CT and opal-CT to quartz are $30^{\circ}$ to $55^{\circ} \mathrm{C}$ and $80^{\circ}$ to $110^{\circ} \mathrm{C}$, respectively (Murata and Larson, 1975 ; Pisciotto, 1978; Hein et al., 1978). The high heat flow at Site 504 not only promoted early formation of secondary quartz-perhaps at temperatures $25^{\circ} \mathrm{C}$ below previously reported values-but also resulted in precipita- 
tion of highly disordered opal-CT $[d(101)=4.131 \AA]$, and permitted little ordering of the opal-CT $[d(101)=$ $4.084 \AA$ ] before its conversion to quartz.

\section{ACKNOWLEDGMENTS}

We appreciate technical and analytical help from Sara Monteith, Robert Oscarson, Rosemary Sliney, and Marla Wilson, U.S. Geological Survey. Susan Karl, Stanford University, and George W. Moore, U.S. Geological Survey, provided critical reviews. Research was completed in conjunction with I.G.C.P. Project 115, Siliceous Deposits of the Pacific Region.

\section{NOTE ADDED IN PROOF}

Work subsequent to the completion of this chapter indicates basement age to be 5.9 instead of 6.2 m.y.

\section{REFERENCES}

Berger, W. H., and von Rad, U., 1972. Cretaceous and Cenozoic sediments from the Atlantic Ocean. In Hayes, D. E., Pimm, A. C., et al., Init. Repts. DSDP, 14: Washington (U.S. Govt. Printing Office), 787-954.

Cook, H. E., Johnson, P. D., Matti, J. C., and Zemmels, I., 1975. Methods of sample preparation and X-ray diffraction data analysis, X-ray mineralogy laboratory, Deep Sea Drilling Project, University of California, Riverside. In Hayes, D. E., Frakes, L. A., et al., Init. Repts. DSDP, 28: Washington (U.S. Govt. Printing Office), 999-1007.

Ekdale, A. A., 1977. Abyssal trace fossils in worldwide Deep Sea Drilling Project cores. In Crimes, T. P., and Harper, J. C. (Eds.), Trace Fossils 2: Liverpool (Seel House Press), pp. 163-182. 1978. Trace fossils in Leg 42A cores. In Hsü, K., Montadert, L., et al., Init. Repts. DSDP, 42, Pt. 1: Washington (U.S. Govt. Printing Office), 821-827.

Ernst, W. G., and Calvert, S. E., 1969. An experimental study of the recrystallization of porcelanite and its bearing on the origin of some bedded cherts. Am. J. Sci., 267-A:114-133.

Flörke, O. W., 1955. Zur Frage des Hoch-Cristobalit in Opalen, Bentoniten und Glasern. Neues Jb. Mineral. MH., 10:217-225.

Gardner, J. V., in press. High-resolution carbonate and organic carbon stratigraphies for the late Neogene and Quaternary from the western Caribbean and eastern equatorial Pacific. In Prell, W. L., Gardner, J. V., et al., Init. Repts. DSDP, 68: Washington (U.S. Govt. Printing Office).

Garrison, R. E., Rowland, S. M., Horan, L. J., and Moore, J. C., 1975. Petrology of siliceous rocks recovered from marginal seas of the western Pacific, Leg 31, Deep Sea Drilling Project. In Karig, D. E., Ingle, J. C., Jr., et al., Init. Repts. DSDP, 31: Washington (U.S. Govt. Printing Office), 519-529.

Hathaway, J. C., 1972. X-ray mineralogy studies-Leg 11, Part 2. In Hollister, C. D., Ewing, J. I., et al., Init. Repts. DSDP, 11: Washington (U.S. Govt. Printing Office), 772-789.

Heath, G. R., 1973. Cherts from the eastern Pacific, Leg 16, Deep Sea Drilling Project. In van Andel, Tj. H., Heath, G. R., et al., Init. Repts. DSDP, 16: Washington (U.S. Govt. Printing Office), 609-613.

Heath, G. R., and Dymond, Jack, 1977. Genesis and transformation of metalliferous sediments from the East Pacific Rise, Bauer Deep, and Central Basin, Northwest Nazca Plate. Geol. Soc. Am. Bull., 88:723-733.

Heath, G. R., and Moberly, R., 1971. Cherts from the western Pacific, Leg 7, Deep Sea Drilling Project. In Winterer, E. L., Riedel, W. R., et al., Init. Repts. DSDP, 7, Pt. 2: Washington (U.S. Govt. Printing Office), 991-1007.

Hein, J. R., Scholl, D. W., Barron, J. A., Jones, M. G., and Miller, J., 1978. Diagenesis of late Cenozoic diatomaceous deposits and formation of the bottom simulating reflector in the southern Bering Sea. Sedimentology, 25:155-181.

Hein, J. R., Vallier, T. L., and Allan, M. A., 1981. Chert petrology and geochemistry, Mid-Pacific Mountains and Hess Rise, Deep Sea Drilling Project, Leg 62. In Vallier, T. L., Thiede, J., et al., Init. Repts. DSDP, 62: Washington (U.S. Govt. Printing Office), 711-748.

Hein, J. R., and Yeh, H-W., 1981. Oxygen-isotope composition of chert from the Mid-Pacific Mountains and Hess Rise, Deep Sea
Drilling Project, Leg 62. In Vallier, T. L., Thiede, J., et al., Init. Repts. DSDP, 62: Washington (U.S. Govt. Printing Office), 749-758.

Iijima, A., Matsumoto, R., and Ryuji, T., 1980. Zeolite and silica diagenesis and sandstone petrography at Sites 438 and 439 off Sanriku, northwest Pacific, Leg 57, Deep Sea Drilling Project. In Scientific Party, Init. Repts. DSDP, 56, 57, Pt. 2: Washington (U.S. Govt. Printing Office), 1143-1158.

Jones, J. B., and Segnit, E. R., 1971. The nature of opal nomenclature and constituent phases. J. Geol. Soc. Australia, 18:57-68.

Kastner, M., Keene, J. B., and Gieskes, J. M., 1977. Diagenesis of siliceous oozes. I. Chemical controls on the rate of opal-A to opalCT transformation-an experimental study. Geochim. Cosmochim. Acta, 41:1041-1059.

Keene, J. B., 1975. Chert and porcelanites from the north Pacific, DSDP Leg 32. In Larson, R. L., Moberly, R., et al., Init. Repts. DSDP, 32: Washington (U.S. Govt. Printing Office), 429-507.

1976. The distribution, mineralogy, and petrography of biogenic and authigenic silica from the Pacific Basin [Ph.D. dissert]. University of California, San Diego.

Keene, J. B., and Kastner, M., 1974. Clays and formation of deep-sea chert. Nature, 249:754-755.

Kelts, K. R., 1976. Summary of chert occurrences from Line Islands DSDP. In Prell, W. L., Gardner, J. V., et al., Init. Repts. DSDP, E. D., et al., Init. Repts. DSDP, 33: Washington (U.S. Govt. Printing Office), 855-865.

Klug, H. P., and Alexander, L. E., 1954. X-ray Diffraction Procedures: New York (Wiley).

Lancelot, Y., 1973. Chert and silica diagenesis in sediments from the central Pacific. In Winterer, E. L., Ewing, J. I., et al., Init. Repts. $D S D P, 17$ : Washington (U.S. Govt. Printing Office), 377-405.

Mayer, L., in press. Physical properties of sediments from Leg 68 Sites 314, 315, 316, DSDP Leg 33. In Schlanger, S. O., Jackson, 68: Washington (U.S. Govt. Printing Office).

Mitsui, K., 1975. Diagenetic alteration of some minerals in argillaceous sediments in western Hokkaido, Japan. Sci. Repts. Tohoku Univ., Ser. 3, 13:1.

Moore, G. W., and Gieskes, J. M., 1980. Interaction between sediment and interstitial water near the Japan Trench, Leg 57, Deep Sea Drilling Project. In von Huene, R., Nasu, N., et al., Init. Repts. DSDP, 56, 57, Pt. 2: Washington (U.S. Govt. Printing Office), 1269-1275.

Murata, K. J., Friedman, I., and Gleason, J. D., 1977. Oxygen isotope relations between diagenetic silica minerals in Monterey Shale, Temblor Range, California. Am. J. Sci., 277:259-272.

Murata, K. J., and Larson, R. R., 1975. Diagenesis of Miocene siliceous shales, Temblor Range, California. U.S. Geol. Survey J. Res., 3:553-566.

Murata, K. J., and Nakata, J. K., 1974. Cristobalite stage in the diagenesis of diatomaceous shale. Science, 184:567-568.

Murata, K. J., and Norman, M. B., 1976. An index of crystallinity of quartz. Am. J. Sci., 276:1120-1130.

Nilsen, T. H., 1976. Turbidites, redbeds, sedimentary structures, and trace fossils observed in DSDP Leg 38 cores and the sedimentary history of the Norwegian-Greenland Sea. In Talwani, M., Udintsev, G., et al., Init. Repts. DSDP, 38: Washington (U.S. Govt. Printing Office), 259-288.

Oehler, J. H., 1973. Tridymite-like crystals in cristobalite "cherts". Nature, 241:64-65.

Pisciotto, K. A., 1978. Basinal sedimentary facies and diagenetic aspects of the Monterey Shale, California [Ph.D. dissert]. University of California, Santa Cruz.

1980. Chert and porcellanite from Deep Sea Drilling Project Site 436, northwest Pacific. In Langseth, M., Okada, H., et al., Init. Repts. DSDP, 56, 57, Pt. 2: Washington (U.S. Govt. Printing Office), 1133-1142.

Riech, V., and von Rad, U., 1979. Silica diagenesis in the Atlantic Ocean: diagenetic potential and transformations. In Talwani, M., Hay, W., and Ryan, W. B. F. (Eds.), Deep Drilling Results in the Atlantic Ocean: Continents, Margins, and Paleonvironments: Washington (Am. Geophys. Union), pp. 315-340.

Sancetta, C. A., in press. Diatom biostratigraphy and paleoceanography from Leg 68, DSDP. In Prell, W. L., Gardner, J. V., et al., Init. Repts. DSDP, 68: Washington (U.S. Govt. Printing Office). 
Schrader, H.-J., 1974. Cenozoic marine planktonic diatom stratigraphy of the tropical Indian Ocean. In Fisher, R. L., Bunce, E. T., et al., Init. Repts. DSDP, 24: Washington (U.S. Govt. Printing Office), 887-967.

Steinberg, M., and Marin, C. M., 1978. Classification géochimique des radiolarites et des sédiments siliceux océaniques, signification paléo-oceanographique. Oceanologica Acta, 1:359-367. von Rad, U., and Rösch, H., 1974. Petrography and diagenesis of deepsea cherts from the central Atlantic. In Hsü, K. J., and Jenkyns, H. C. (Eds.), Pelagic Sediments on Land and under the Sea: Spec. Publ. Internat. Assoc. Sedimentol., 1:327-347.

Wilson, M. H., Russell, J. D., and Tait, J. M., 1974. A new interpretation of the structure of disordered cristobalite. Contr. Mineral. Petrol., 47:1-6. 


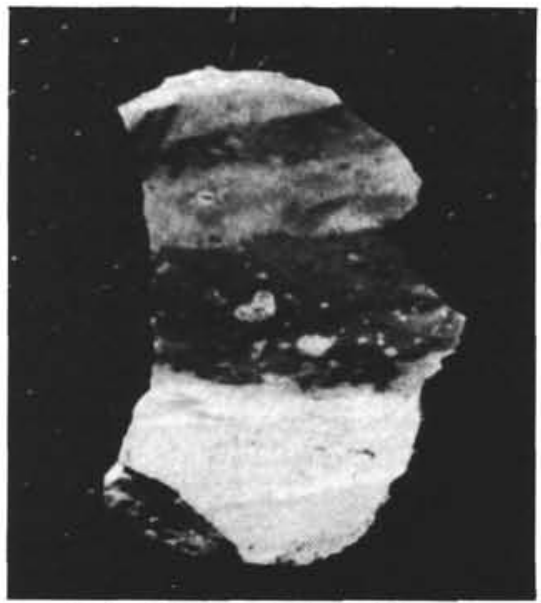

DSDP 504A-5-1, 75-78 cm

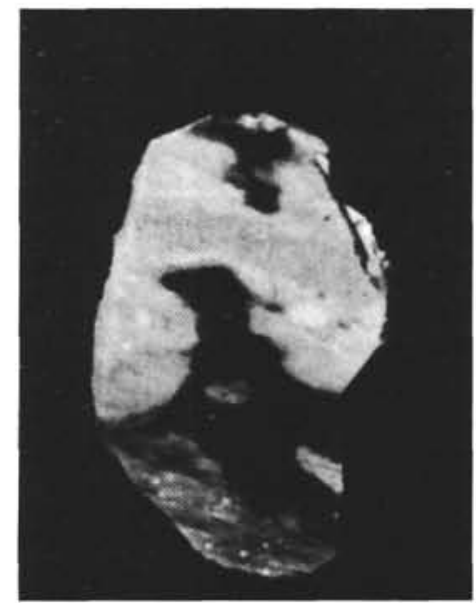

DSDP 504A-5-1, 70-72 cm
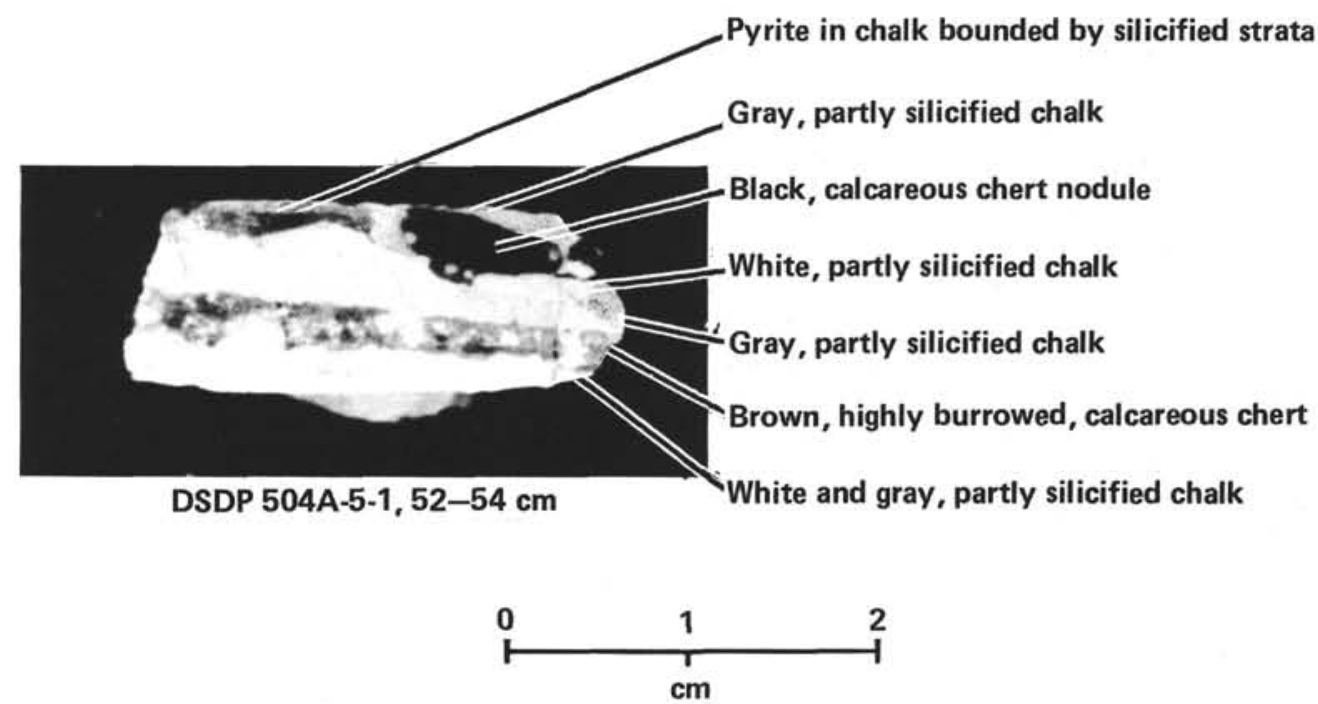

Plate 1. Photographs of chalk, chert and porcellanite. 1. Partly silicified, mildly burrowed chalk (gray), alternating with three extensively burrowed laminae replaced by chert (dark gray). 2. Gray, calcareous porcellanite (light colored), containing two large chert-filled burrows (dark gray). The area below the largest chert burrow is opal-CT-quartz porcellanite. 3. Laminated, silicified, and pyritized chalk. The chert nodule may represent a large chert-filled burrow(?). Chalk laminae do not contain recognizable burrows, whereas the chert replaced an extensively burrowed chalk layer. In addition, a relict texture of the chert lamina suggests that more biogenic silica may have been available in this layer to aid silicification than was available in surrounding chalk laminae. 

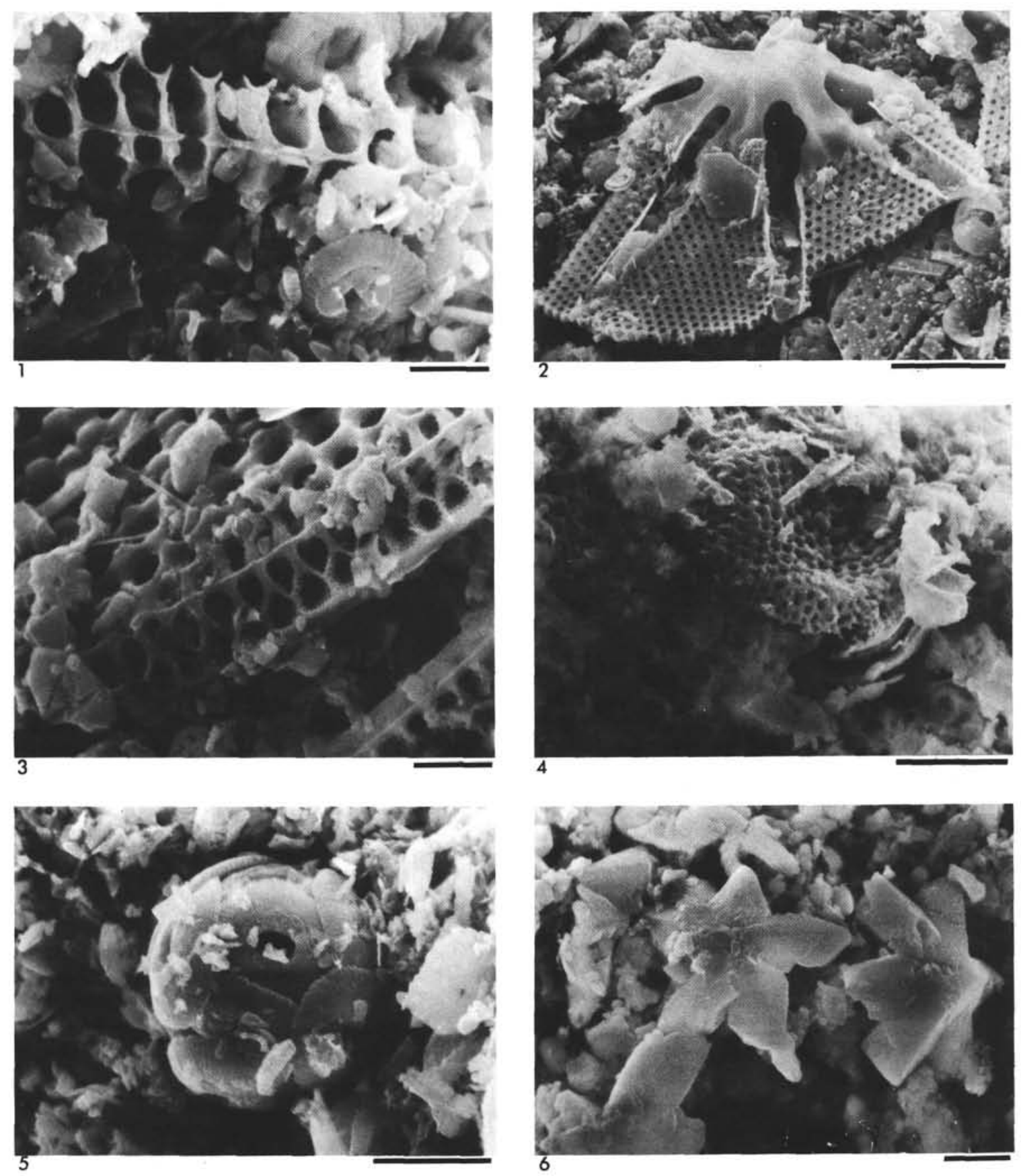

Plate 2. SEM photomicrographs of chalks. $1.504-52-1,94 \mathrm{~cm}$. Siliceous chalk, showing only very mild dissolution of diatom and coccoliths overgrown with calcite. Most of the fine-grained carbonate matrix is disaggregated coccolith plates. Scale is $2 \mu \mathrm{m}$. 2 . 504-52-1, $94 \mathrm{~cm}$. Siliceous chalk, showing concentration of diatoms. Diatoms are commonly fragmented but not etched in chalks stratigraphically above about 235 meters. Large central diatom is an Asterolampra. Scale is $10 \mu \mathrm{m}$. 3. 504-53-1, $10 \mathrm{~cm}$. Siliceous chalk within a few centimeters above the first major occurrence of chert. Diatoms still show many delicate structures. Large diatom is a Coscinodiscus nodulifer. Scale is $3 \mu \mathrm{m}$. $4.504 \mathrm{~A}-5-1,70 \mathrm{~cm}$. Partly silicified chalk from near the base of the chert section, showing much corrosion and loss of delicate structure of diatoms. These diatoms probably were saved from dissolution by protective coatings of iron. Scale is $9 \mu \mathrm{m}$. 5. 504-52-1, $94 \mathrm{~cm}$. Siliceous chalk, showing a delicate coccosphere. This sample also has overgrown nannofossils, fragmented diatoms (compare with Plate 2, Figs. 1, 2), and flattened foraminifers (seen in thin-sections). The fine carbonate matrix is coccolith plates. Scale is $6 \mu \mathrm{m}$. 6. 504A-1,CC I. Calcareous porcellanite, showing overgrown Discoaster quinqueramus and $D$. variabiliz and fine-grained calcite and silica cement. Much of the fine carbonate cement no longer can be identified as coccolith plates. Scale is $3 \mu \mathrm{m}$. 

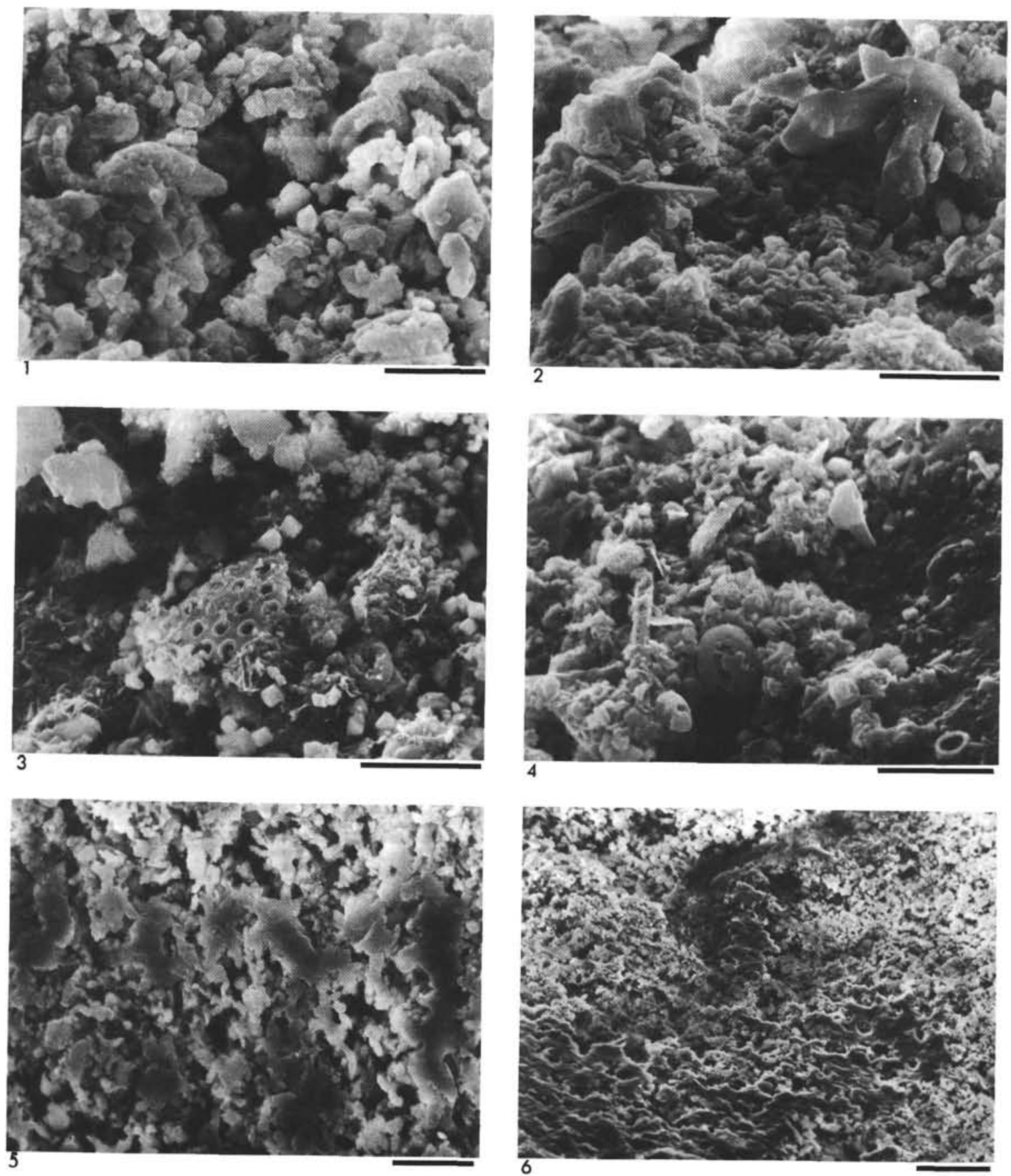

Plate 3. SEM photomicrographs of partly silicified chalks. $1.504 \mathrm{~A}-5-1,70 \mathrm{~cm}$. Partly silicified chalk, showing very poorly preserved, recrystallized, fragmented nannofossils in secondary calcite and silica cement. EDAX shows that $\mathrm{Ca} / \mathrm{Si}=6.7$ for this field view. Scale is $6 \mu \mathrm{m}$. $2.504 \mathrm{~A}-5-1$, $70 \mathrm{~cm}$. Partly silicified chalk, showing greatly different degrees of overgrowth on two adjacent discoasters. Many fractures occur in the secondary calcite on the upper right discoaster. Coccolith matrix. Scale is $10 \mu \mathrm{m}$. 3. $504 \mathrm{~A}-3-1,90 \mathrm{~cm}$. Partly silicified chalk, showing coccolith and diatom fragments in bladed opal-CT and granular calcite cements. Scale is $6 \mu \mathrm{m}$. 4. 504-53-1, $10 \mathrm{~cm}$. First major occurrence of secondary silica, showing siliceous chalk containing many diatom fragments, in sharp contact with massive opal-CT chert. Many nannofossil impressions and fragments similar to those in Plate 4, Figure 5 occur in the opal-CT chert. Scale is $9 \mu \mathrm{m}$. $5.504 \mathrm{~A}-5-1,61 \mathrm{~cm}$. Silicified chalk, showing only vague outlines of original nannofossils. Mostly silica cement and replaced nannofossils. EDAX shows very little Ca. Scale is $10 \mu \mathrm{m}$. 6. 504A-1,CC II. Patchy silicification of chalk, silica cemented and replaced nannofossils. EDAX of denser patches shows only $\mathrm{Si}$; whole field of
view shows $\mathrm{Si}$ and minor Ca. Scale is $30 \mu \mathrm{m}$. 

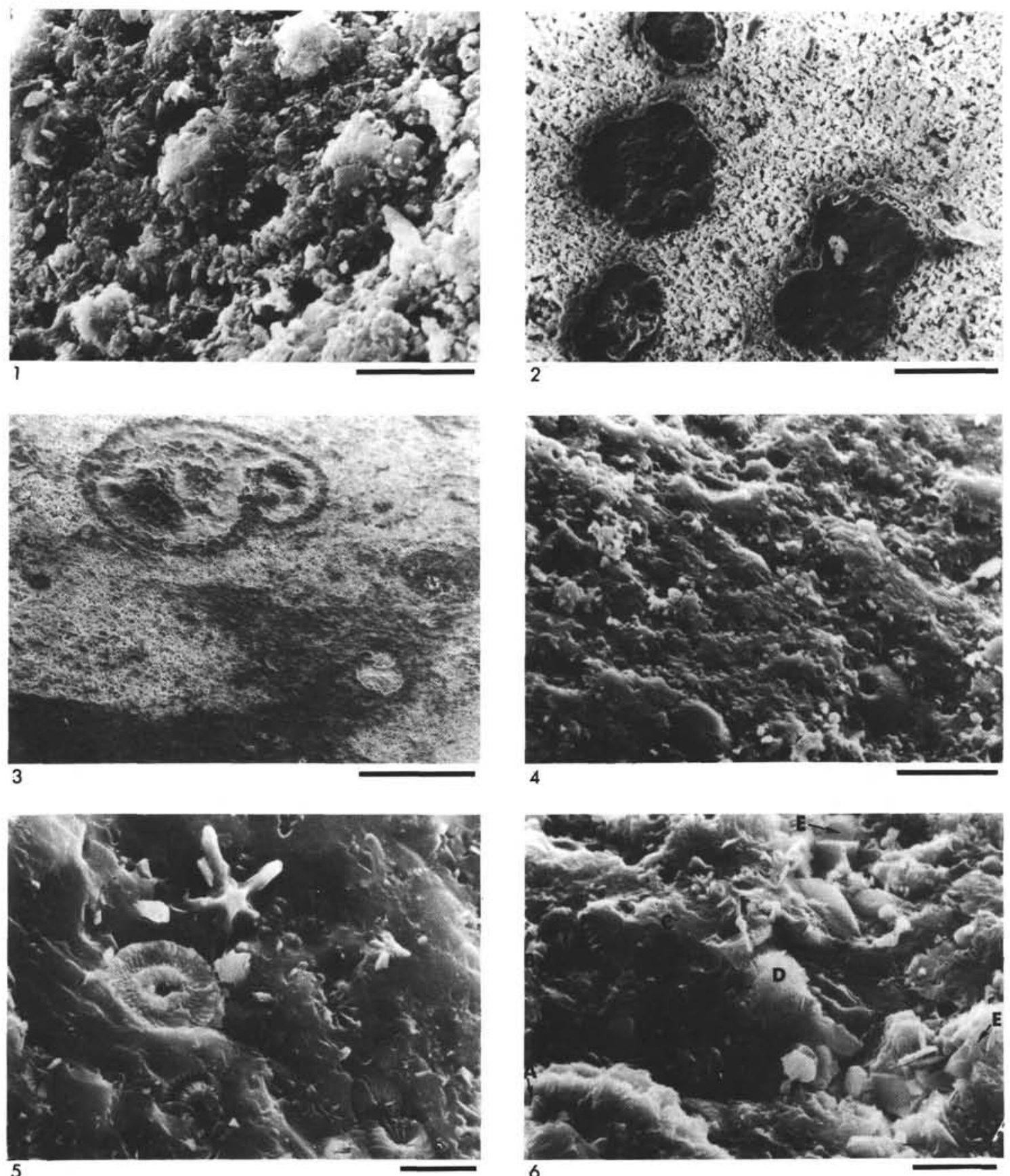

Plate 4. SEM photomicrographs of porcellanite and chert. 1. 504-53-1, $10 \mathrm{~cm}$. Opal-CT chert, showing coccoliths replaced by opal-CT. A detailed description of the evolution of this texture is provided by Hein et al. (1981). Scale is $10 \mu \mathrm{m}$. 2. 504A-2,CC. Radiolarians and foraminifers filled with dense silica in very porous silica-cemented and -replaced chalk (porcellanite). Foraminifer test walls are replaced by silica, whereas the radiolarian test dissolved, leaving a void (uppermost test). Scale is $60 \mu \mathrm{m}$. 3. $504 \mathrm{~A}-5-1,70 \mathrm{~cm}$. Contact of two textures (probably burrow contact). The upper is a porous, light-gray, silica-replaced chalk, composed solely of silica; the lower is massive silica, and porosity decreases away from the contact; again $\mathrm{Ca}$ is absent. The large foraminifer in the porous area was filled with chalcedony first, then coarse-grained quartz (dark area at the center of each chamber). The small foraminifer in the lower right is filled with chalcedony. Scale is $200 \mu \mathrm{m} . \quad 4.504 \mathrm{~A}-2, \mathrm{CC}$. Nannofossil impressions and fragments in calcareous porcellanite (massive opal-CT). EDAX shows that $\mathrm{Ca} / \mathrm{Si}=0.25$ for field of view. Scale is $10 \mu \mathrm{m}$. 5. 504A-5-1, $70 \mathrm{~cm}$. Nannofossil impressions and fragments in calcareous chert (massive quartz + opal-CT). EDAX shows that $\mathrm{Ca} / \mathrm{Si}=0.20 \mathrm{for}$ field of view. Scale is $6 \mu \mathrm{m}$. 6. 504A-2,CC. Calcareous porcellanite, showing a wide variety of secondary phases: (A) recrystallized wall of foraminifer, (B) pyrite framboid in void, (C) massive quartz that grades into bladed silica at the pyrite framboid void wall, (D) opal-CT lepisphere, (E) euhedral calcite crystals. Scale is $6 \mu \mathrm{m}$. 

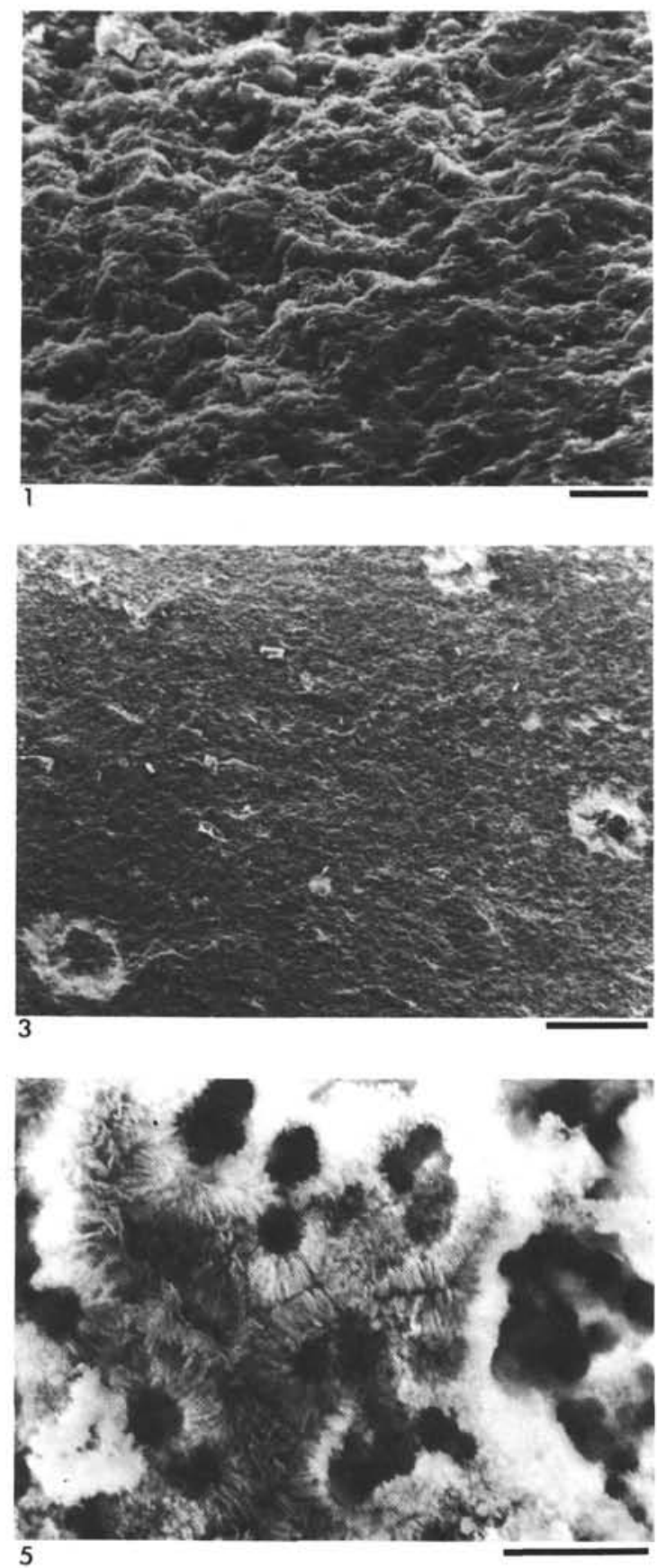
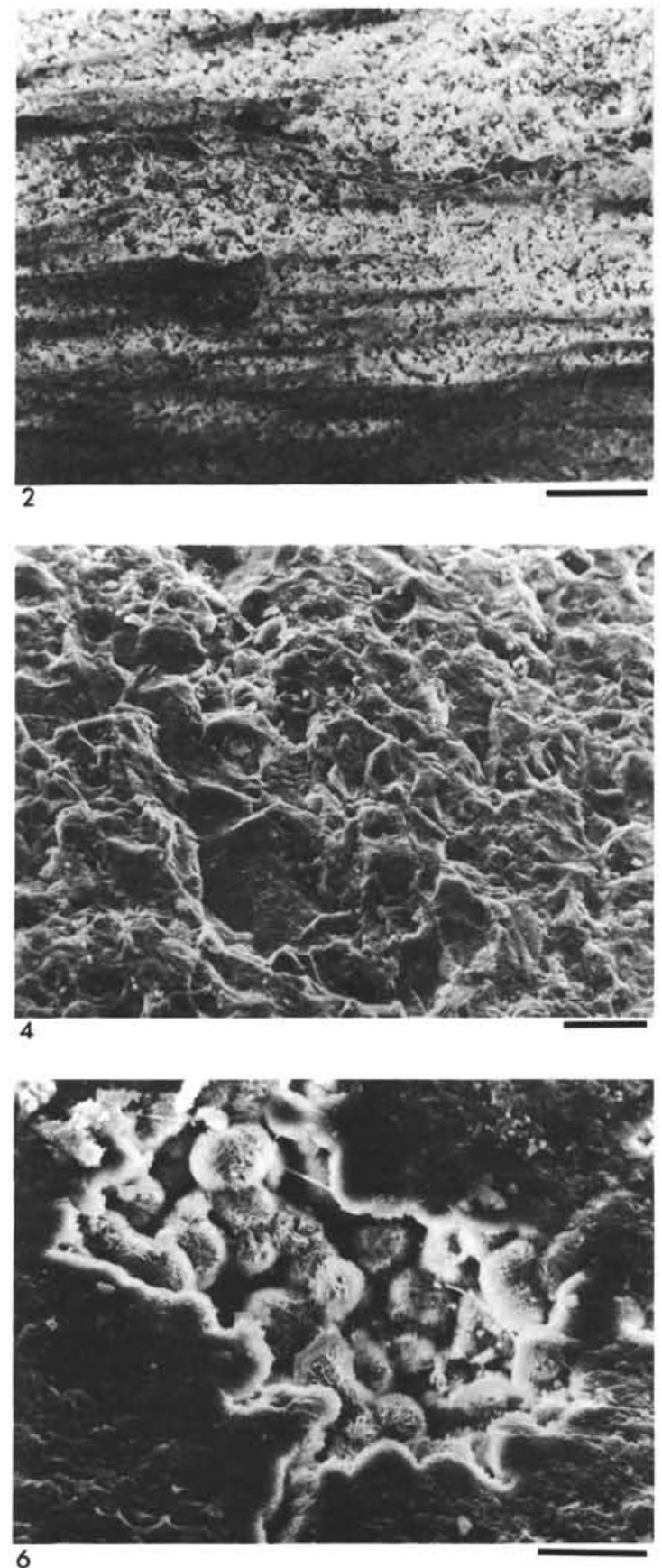

6

Plate 5. SEM photomicrographs of porcellanite, chert, and microfossils. $1.504 \mathrm{~A}-5-1,52 \mathrm{~cm}$. Partly silicified chalk with many nannofossils and most of the original porosity lost to silica and calcite cement $(\mathrm{Ca} / \mathrm{Si}=1.25 ;$ left $2 / 3$ of photo), in contact with dense, massive chert, $(\mathrm{Ca} / \mathrm{Si}$ $<0.01$ ). Scale is $10 \mu \mathrm{m}$. 2. $504 \mathrm{~A}-5-1,70 \mathrm{~cm}$. Weakly silicified chalk (white) and streaks and laminae of chert (dark gray). Scale is 60 $\mu \mathrm{m}$. 3. 504-4-1, $110 \mathrm{~cm}$. Dense, massive silica typical of quartz chert. Note three radiolarians(?) filled with chalcedony and microgranular quartz. Scale is $100 \mu \mathrm{m} . \quad 4.504 \mathrm{~A}-5-1,37 \mathrm{~cm}$. The coarsest-grained chert studied from Leg 69 rocks. This quartz chert also has the highest quartz crystallinity value (2.1; Table 1). Scale is $30 \mu \mathrm{m}$. 5. 504-53-1, $10 \mathrm{~cm}$. Part of an opal-CT-replaced diatom or radiolarian from an opal-CT chert. Scale is $10 \mu \mathrm{m}$. 6. 504A-2,CC. Calcareous porcellanite with typical void filled with opal-CT lepispheres. Most voids of this nature were probably parts of foraminifer chambers. Scale is $20 \mu \mathrm{m}$. 

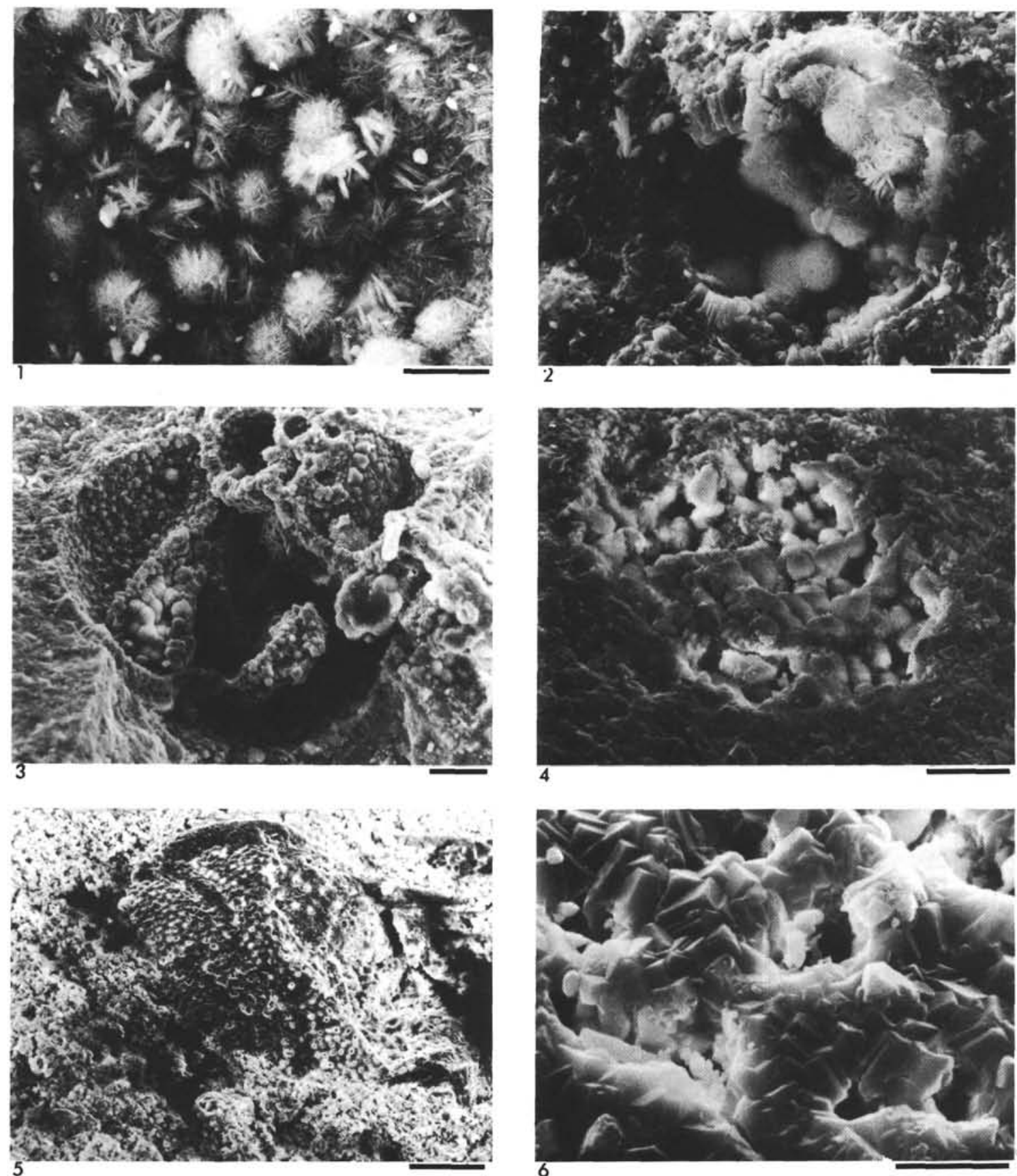

Plate 6. SEM photomicrographs of microfossils. 1. 504A-3-1, $100 \mathrm{~cm}$. Well-developed opal-CT lepispheres and packets of blades filling a chamber of a foraminifer. Scale is $10 \mu \mathrm{m}$. 2. 504A-3-1, $59 \mathrm{~cm}$. Foraminifer with one chamber full of opal-CT lepispheres, one with lepispheres and secondary calcite, and one nearly empty, containing only one lepisphere. Scale is $10 \mu \mathrm{m}$. 3. 504A-5-1, $70 \mathrm{~cm}$. Foraminifer with chambers filled with various combinations of calcite and opal-CT. Scale is $30 \mu \mathrm{m}$. 4. 504A-5-1, $8 \mathrm{~cm}$. Opal-CT lepispheres and quartz filling a radiolarian(?) mold. Lepispheres coalesced and lost much of their bladed form. This is typical of opal-CT being converted to quartz (Hein et al., 1981). Scale is $20 \mu \mathrm{m}$. 5. 504A-1,CC I. Strongly recrystallized foraminifer. Scale is $60 \mu \mathrm{m}$. 6. 504A-1,CC I. Detail of calcite crystals of recrystallized foraminifer in Plate 6, Figure 5. Scale is $6 \mu \mathrm{m}$. 

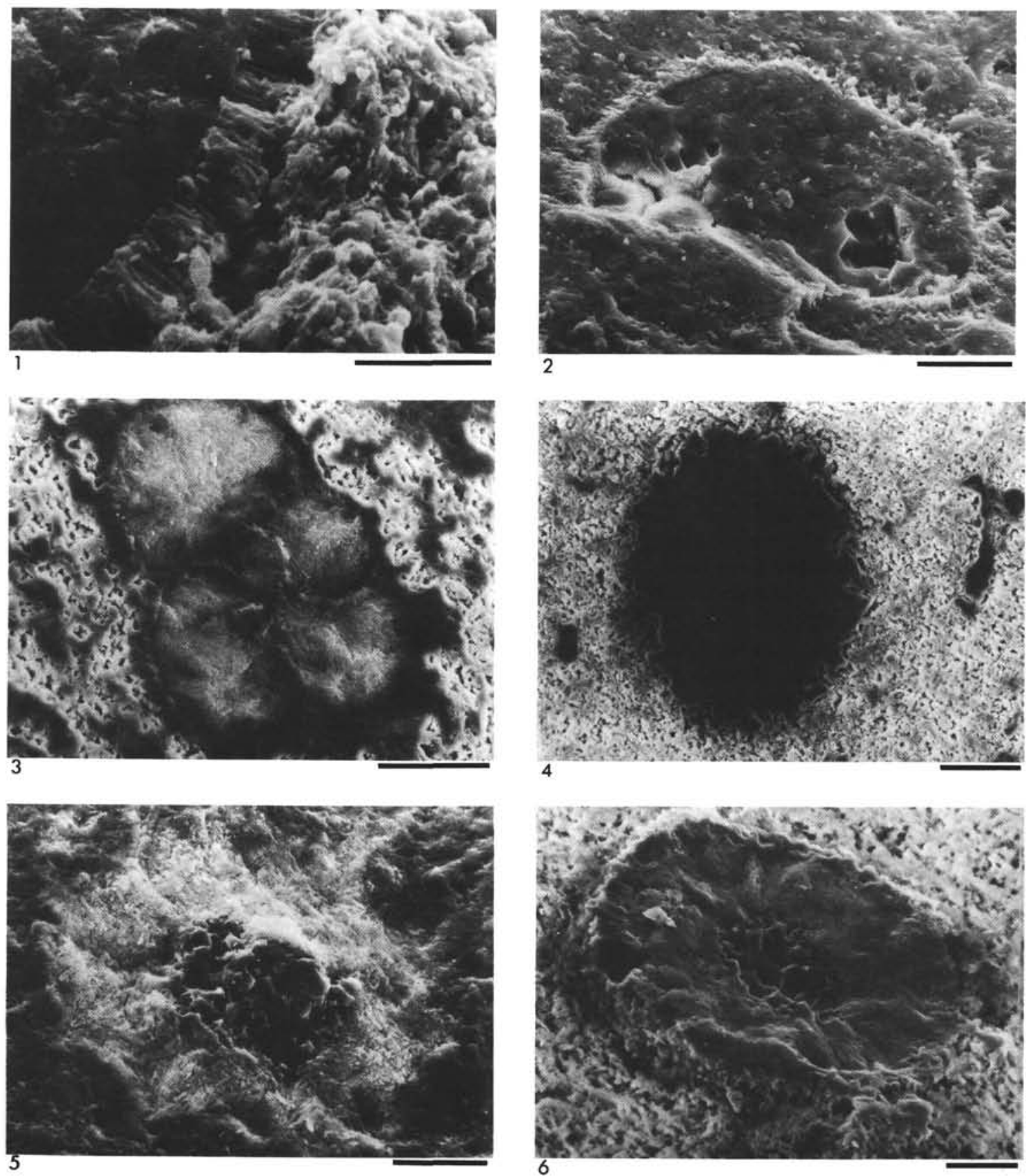

Plate 7. SEM photomicrographs of microfossils. 1. 504A-5-1, $70 \mathrm{~cm}$. Wall of foraminifer separating massive quartz chamber filling to the left and host calcareous chert to the right. The test wall is partly replaced by $\mathrm{SiO}_{2}$. Scale is $10 \mu \mathrm{m}$. 2. 504A-5-1, 70 cm. Foraminifer in advanced stage of diagenesis in chert. Bright areas (left center) are probably recrystallized or quartz-replaced lepispheres. Scale is $20 \mu \mathrm{m}$. 3. 504A-5-1, 70 $\mathrm{cm}$. Foraminifer with all chambers filled with chalcedony. Walls are replaced by silica which has grown into the host chert as overgrowths. Scale is $30 \mu \mathrm{m}$. 4. $504 \mathrm{~A}-5-1,61 \mathrm{~cm}$. Very dense, massive quartz filling radiolarian(?) mold. Scale is $60 \mu \mathrm{m}$. 5. 504A-4-1, 110 cm. Radiolarian(?) filled first with chalcedony and then with microcrystalline quartz. Host rock is massive chert. Scale is $20 \mu \mathrm{m}$. $6.504 \mathrm{~A}-5-1,70 \mathrm{~cm}$. Radiolarian or foraminifer filled first with chalcedony and then with microcrystalline quartz in a host rock of porous, partly silicified chalk. Scale is $30 \mu \mathrm{m}$. 

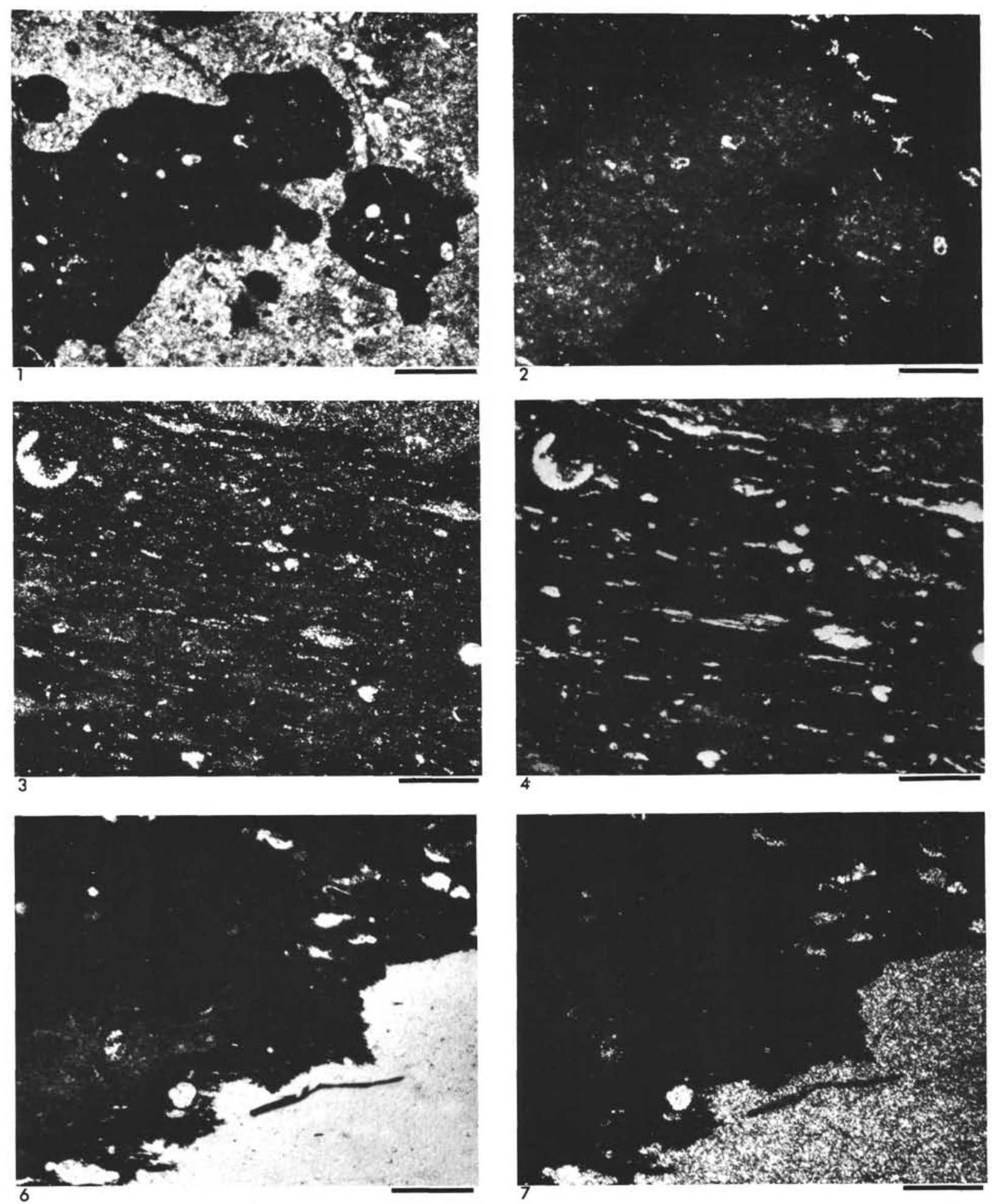

Plate 8. Thin-section photomicrographs of textures of siliceous rocks. 1. 504A-5-1, $52 \mathrm{~cm}$. Extensively burrowed calcareous chert layer (light) with projection of chalk from upper layer (dark). See Plate 1, Figure 3. Plane light; scale is $0.64 \mathrm{~mm}$. 2. As above, crossed polarizers. Burrowed chert layer is a fine mixture of opal-CT (dark) salted with quartz (light). 3. 504A-5-1, $8 \mathrm{~cm}$. Preferred orientation of elongate grains and quartz and opal-CT stringers. Many elongate grains are flattened foraminifers that were replaced and filled with quartz. Plane light; scale is 0.64 mm. 4. As above, crossed polarizers. $5.504 \mathrm{~A}-1-5,75 \mathrm{~cm}$. Transition from quartz burrow (lower right) to partly silicified chalk (upper left). These two lithologies are separated by an opal-CT rim on the quartz burrow (diagonal band, center of view). Plane light; scale is $0.64 \mathrm{~mm}$. 6. As above, crossed polarizers. Opal-CT rim is dark band from lower left to upper right. 

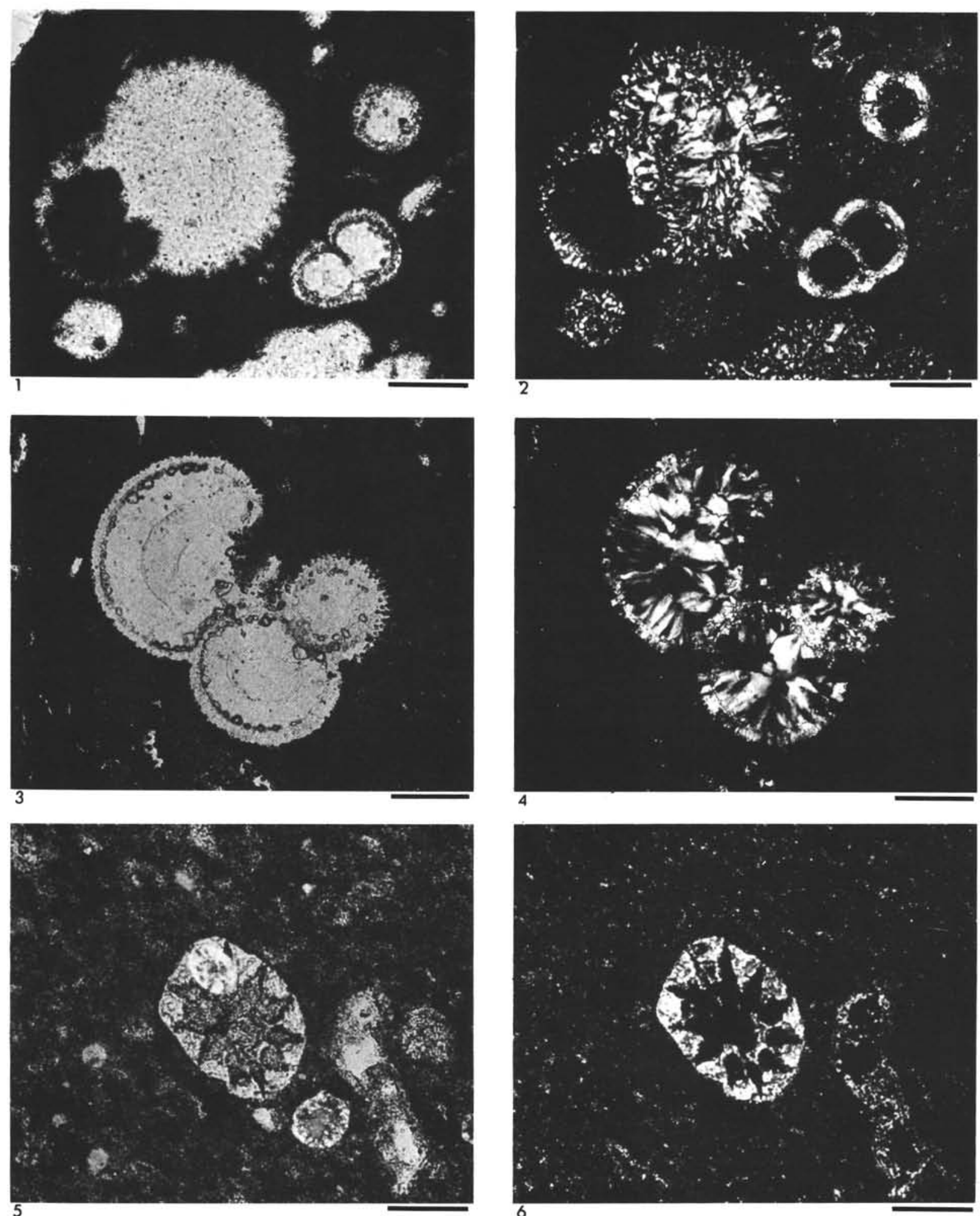

Plate 9. Thin-section photomicrographs of microfossils. 1. 504A-3-1, $59 \mathrm{~cm}$. Foraminifer with one chamber filled with opal-CT and another with chalcedony. The two foraminifers to the right have calcite walls and empty chambers. Most of the host rock is opal-CT. Plane light; scale is $0.16 \mathrm{~mm}$. 2. As above, crossed polarizers. 3. 504A-3-1, $103 \mathrm{~cm}$. Chalcedony-filled and -replaced foraminifer in opal-CT. A thin layer of secondary calcite that was probably precipitated on the interior of the chamber walls separates the chalcedony chamber filling from the chalcedony-replaced wall. Plane light; scale is $0.16 \mathrm{~mm}$. 4. As above, crossed polarizers. 5. 504A-4-1, $81 \mathrm{~cm}$. Opal-CT-filled, recrystallized foraminifer in matrix consisting of a fine mixture of opal-CT and calcite. Plane light; scale is $0.16 \mathrm{~mm}$. 6. As above, crossed polarizers. 

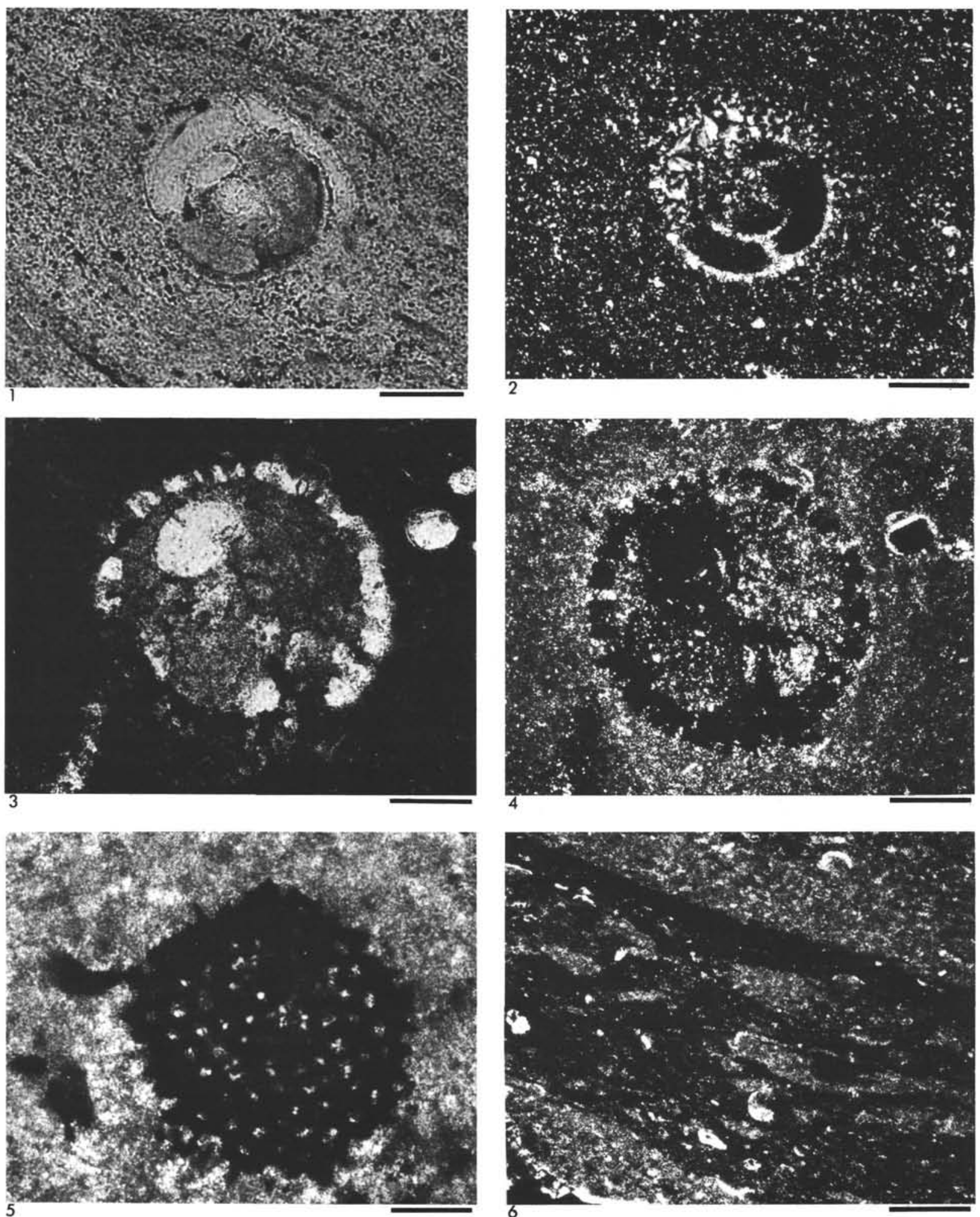

Plate 10. Thin-section photomicrographs of microfossils and pyrite. $1.504 \mathrm{~A}-5-1,37 \mathrm{~cm}$. Foraminifer replaced and filled by chalcedony at the upper left, whereas the lower right half of the test is recrystallized calcite and is filled with opal-CT. The matrix is a fine mixture of calcite, quartz, and opal-CT. Plane light; scale is $0.16 \mathrm{~mm}$. 2. As above, crossed polarizers. 3. 504A-3-1, $10 \mathrm{~cm}$. Radiolarian replaced by pyrite and opal-CT and filled with opal-CT, quartz, and calcite. Matrix is opal-CT, quartz, and calcite. Plane light; scale is $0.16 \mathrm{~mm}$. 4 . As above, crossed polarizers. 5. 504A-3-1, $100 \mathrm{~cm}$. Pyrite-replaced radiolarian in calcareous porcellanite. Plane light; scale is $0.04 \mathrm{~mm}$. $6.504 \mathrm{~A}-5-1,52 \mathrm{~cm}$. Several-millimeter-thick layer of pyrite laminae and lenses in partly silicified chalk. See Plate 1, Figure 3. Crossed polarizers; scale is 0.64 mm. 

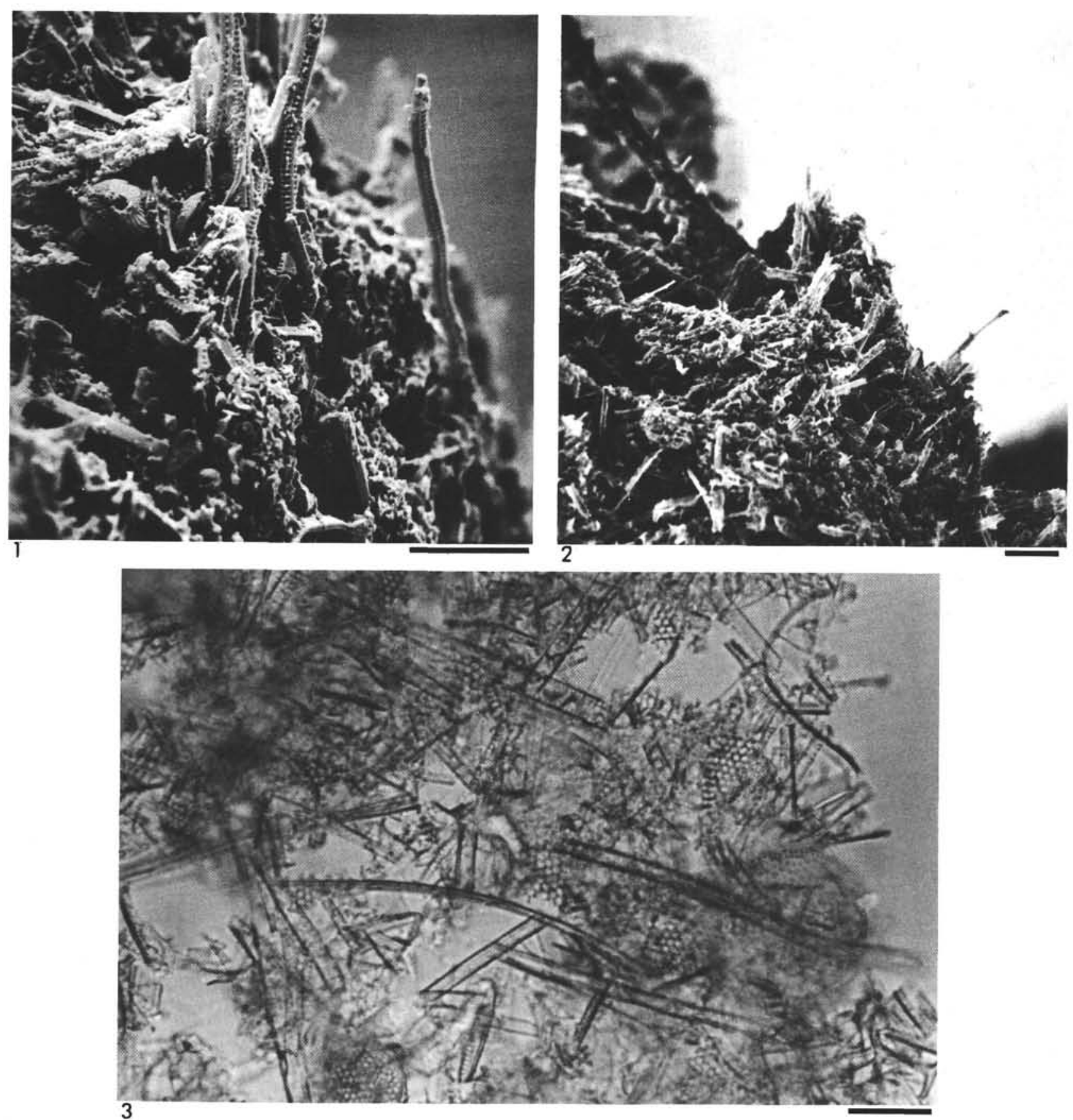

Plate 11. Photomicrographs of untreated samples from 504-53,CC, showing high abundance of Thalassionema diatoms. 1. SEM photomicrograph, showing excellent preservation of diatoms. Scale is $10 \mu \mathrm{m}$. 2. SEM photomicrograph. Abundant needle-like diatoms produce a porous, unconsolidated texture, although this sample is within 10 meters of the first chert encountered. Scale is $10 \mu \mathrm{m}$. 3. Photomicrograph from a smear slide. Scale is $10 \mu \mathrm{m}$. 

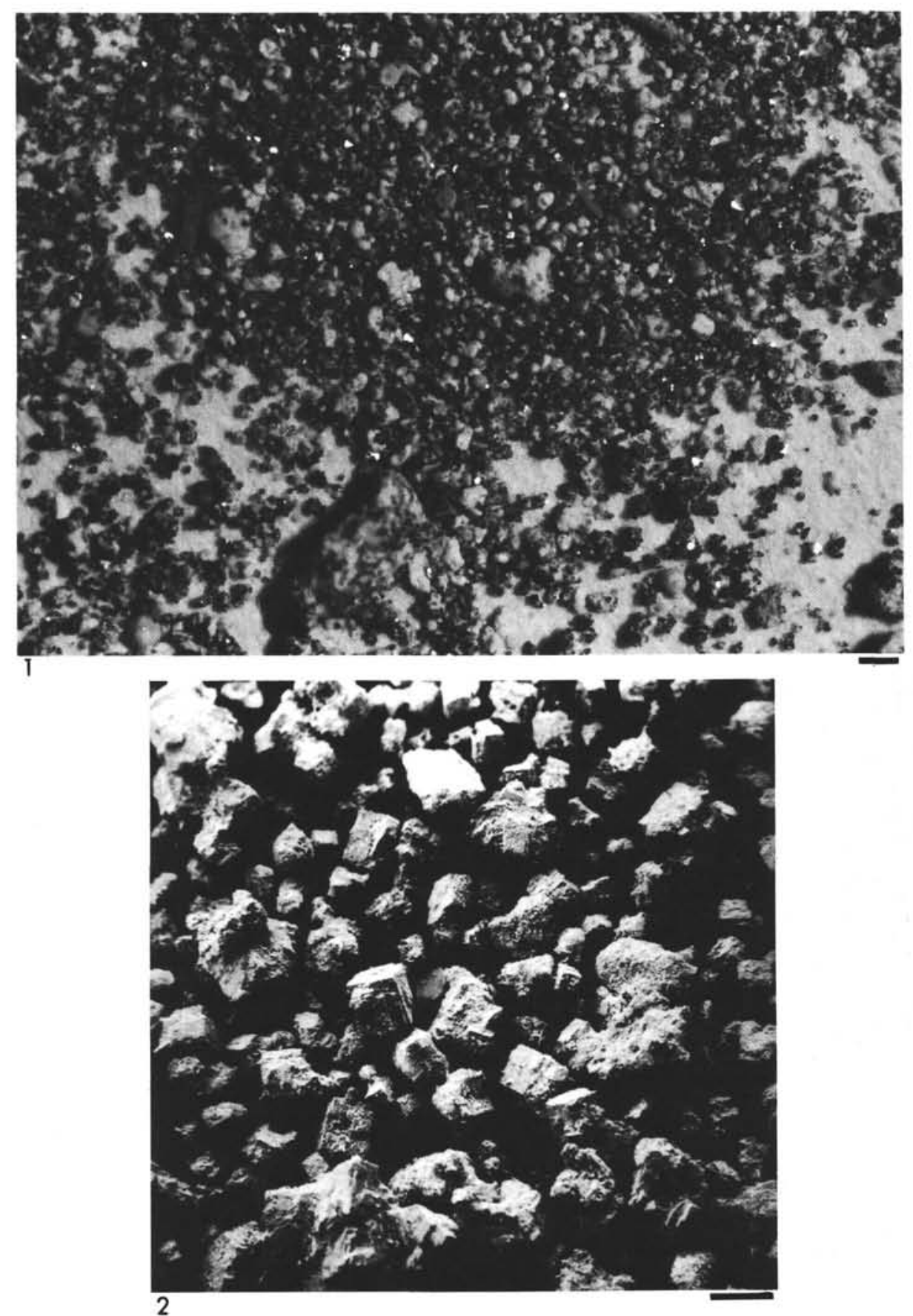

Plate 12. Photomicrographs of the coarse size fraction $(>63 \mu \mathrm{m})$ from 504-52,CC, showing concentrations of pyrite. This interval may represent a diagenetic front. 1. Photomicrograph of strew sample, fragments of foraminifers and abraded sponge spicules accompany the pyrite. Reflected light; scale is $200 \mu \mathrm{m}$. 2. SEM photomicrograph. Pyrite occurs mainly as cubic crystals. Scale is $100 \mu \mathrm{m}$. 

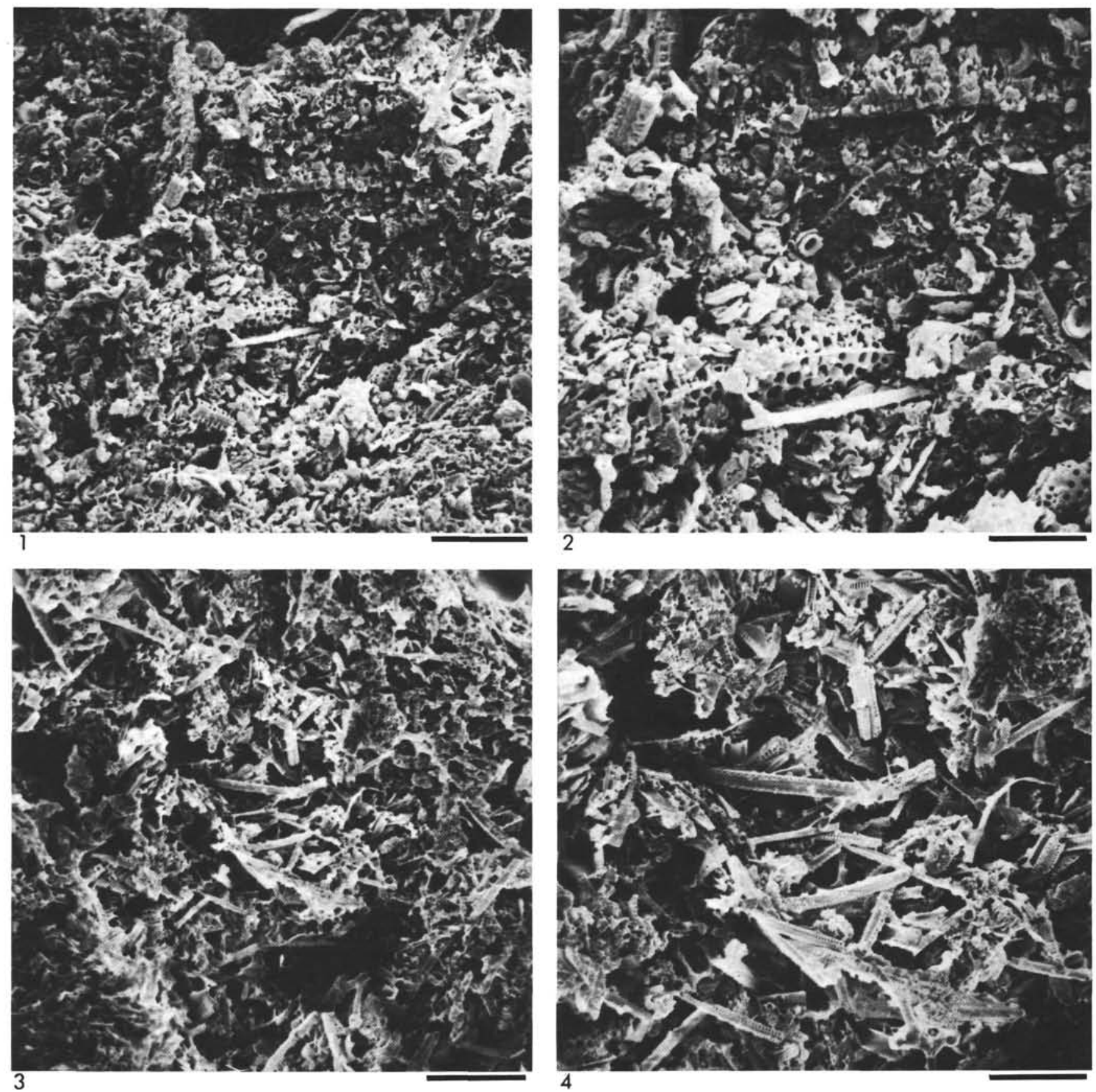

Plate 13. SEM photomicrographs comparing sediment textures in chalk and in sediment stratigraphically just above the first chert. 1. Untreated chalk, 504-48,CC. General view. Scale is $40 \mu \mathrm{m}$. 2. Close view of chalk, 504-48,CC. Scale is $20 \mu \mathrm{m}$. 3. Untreated diatom-rich calcareous ooze, 504-53,CC, from just above the chert section. Concentration of needle-like diatom species produces an open-mesh, unconsolidated texture, exposing large surface area to dissolution. General view. Scale is $40 \mu \mathrm{m}$. 4. Close view of 504-53,CC. Scale is $20 \mu \mathrm{m}$. 